\title{
The Breede River estuary (Cape Province, South Africa): A historical perspective on hydrology, geomorphology, and sedimentology
}

\author{
Burg Flemming $^{1}$ (D) $\cdot$ Keith Martin ${ }^{2}$
}

Received: 19 October 2020 / Accepted: 26 January 2021 / Published online: 25 February 2021

(C) The Author(s) 2021

\begin{abstract}
A hitherto unpublished historical dataset of the Breede River estuary, Western Cape, South Africa, that was collected in the summer season of 1983 is presented. Bathymetric, physiographic, and sedimentological data were collected at $1-1.5-\mathrm{km}$ intervals between the mouth and the Malgas ferry crossing at $\mathrm{km} \mathrm{35}$. The remaining estuary up to $\mathrm{km} 52$ was not surveyed. Sedimentologically, the estuary could be divided into a lower marine sand reach (mouth to $\mathrm{km} 5$ ), a mixed sand/mud reach

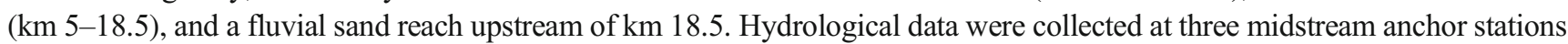

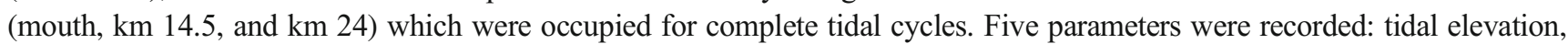
current velocity, salinity, temperature, and light transmittance. Pronounced velocity asymmetries of the tides were revealed by phase delays between the times of low (high) water and corresponding slack water (turn of the tide), as well as considerable upestuary delays in the occurrence of high and low tides. The mode of tidal wave propagation was synchronic (constant height) up to a distance of $\sim 23 \mathrm{~km}$ at spring high tide and $\sim 13 \mathrm{~km}$ at neap high tide, from where it proceeded in hyposynchronic mode (progressive decrease in height). Peak surface velocities reached $1.5 \mathrm{~m} / \mathrm{s}$ at Station 1 (mouth), $0.6 \mathrm{~m} / \mathrm{s}$ at Station 2 (km 14), and $0.45 \mathrm{~m} / \mathrm{s}$ at Station $3(\mathrm{~km} \mathrm{24})$. The marine sand reach and parts of the mixed sand/mud and fluvial sand reaches were distinctly flood dominated as revealed by the orientation of bedforms. Salt water intrusion reached up to $\mathrm{km} 25$, where river background levels were reached. Suspended sediment concentrations (turbidity) varied from $55-85 \mathrm{mg} / \mathrm{l}$ at the mouth, $65-200 \mathrm{mg} / \mathrm{l}$ in the mixed sand/mud reach, and 55-85 mg/l in the fluvial sand reach. At the time of observation, the Breede River estuary was in a well-mixed hydrological state. The fluvial sand reach displayed numerous, up to 18-m-deep scour pools. Grain-size distributions revealed distinct differences between the individual estuary sections, the sand/mud, and marine sand reaches, in particular, being characterized by up to four, mostly mixed hydraulic populations. Offshore seismic profiles suggest that the Duiwenhoks River, located $14 \mathrm{~km}$ to the east of the Breede mouth, was a tributary of the latter during Pleistocene sea-level lowstands. From a global perspective, the Breede River estuary conforms physically to typical small estuaries that are only marginally impacted by human interferences.
\end{abstract}

Keywords Breede River - South Africa · southern Cape Province · hydrology · suspended sediment concentration · geomorphology $\cdot$ scour pools $\cdot$ sedimentology $\cdot$ bedforms $\cdot$ flood domination $\cdot$ Holocene evolution

This article is part of the Topical Collection on Coastal and marine geology in Southern Africa: alluvial to abyssal and everything in between

Burg Flemming

bflemming@senckenberg.de

1 Senckenberg, Südstrand 40, 26382 Wilhelmshaven, Germany

2 Avenida de la Vega 8, Portal 1, 1B, 28108 Alcobendas, Spain

\section{Introduction}

River discharge, tidal prism, river plan form, and sedimentology of estuaries are closely interlinked parameters. These, in turn, affect the local tidal symmetry or asymmetry along estuaries from their mouths to the upstream limits of tidal wave propagation (Dronkers 1986, 2005; Friedrichs 1995; Prandle 2009). In a geological context, estuaries are commonly divided into three domains, a wave-dominated and tide-dominated lower domain characterized by sands of marine origin, a mixed-energy domain characterized by muddy sediment, and a river-dominated domain characterized by fluvial sands 
or gravels, or both (e.g., Dionne 1963; Nichols 1972; Dalrymple et al. 1992; Perillo 1995). Depending on the environmental situation, individual domains may expand or shrink at the expense of the others (e.g., Cooper et al. 1999; Schettini et al. 2010).

As foremost junctures between the sea and the terrestrial hinterland, estuaries act as transfer and storage systems for freshwater runoff and their dissolved, suspended, and bed load materials. Due to increasing human pressures and interventions, estuaries have become the most heavily impacted aquatic (eco)systems on earth (Barbier et al. 2011). Being ecosystems of outstanding ecological, recreational, and commercial value (cf. Kennish 2016a), their protection and management have received high priority in the political agendas of many countries (cf. Kennish 2016b). South Africa is no exception in this context.

Studies of South African estuaries predominantly dealt with biological and ecological aspects and their state of pollution and water quality (e.g., Day 1981; Allanson and Baird 1999; Taljaard et al. 2001; Schumann 2003; Lamberth et al. 2008; Taljaard et al. 2009; Cullis et al. 2018; and citations therein). In more recent years, the focus shifted to classification criteria for management purposes and priorities (e.g., Coetzee et al. 1996; Turpie et al. 2002; Taljaard 2003; Whitfield et al. 2012; Adams 2020; van Niekerk et al. 2020). Notably, in terms of conservation importance, the Breede River has been ranked as number 18 among the top 50 estuaries (Turpie et al. 2002). Unfortunately, comprehensive information on all the relevant aspects rarely exists for any single estuary (e.g., Schumann 2003; Whitfield et al. 2012). Being blessed with about 290 estuaries, their effective management inevitably requires a priority ranking based on scientifically accrued information. Besides basic physical data, knowledge about ecological functions and interactions play an important role in this context (e.g., McLachlan and Grindley 1971; Day 1981; Whitfield et al. 2012, to name just three typical examples). For example, sediment composition has been recognised as an important factor in the distribution and structure of eurohaline macrofaunal communities (e.g., McLachlan and Grindley 1974; Perkins 1974; Day 1981) and, by implication, for the distribution of particular fish assemblages that selectively feed on this fauna (e.g., Lamberth et al. 2008; Barletta and Dantas 2016).

In comparison to the wealth of biological and (geo)chemical studies, much fewer investigations have been concerned with morphological and/or sedimentological aspects of South African estuaries (e.g., Reddering 1983, 1988; Reddering and Rust 1990; Illenberger 1991, 1992; Cooper 2001; Cooper et al. 2012; Schumann 2003; Beck 2005; Schumann 2015; de Lecea et al. 2016; cf. also references in these publications). Many of these studies were regionally concentrated, in particular in the Eastern Cape Province and KwaZulu-Natal (cf. Schumann 2003). In addition, much important data are contained in unpublished and difficult to access theses and reports (e.g., Duvenage 1983, Reddering and Esterhuysen 1984, to name just two). This also applies to the Breede River estuary (Flemming and Martin 1983; de Villiers 1988).

Systematic overviews of available information, including hydrological data and associated literature sources up to 1978 , were compiled by Begg (1978) for the estuaries of Natal, and up to the late 1980s by Heydorn and Tinley (1980), Heydorn and Grindley (1982), and Heydorn and Morant (1989) for the Cape Province. The most recent comprehensive bibliographic overview of South African estuaries has been compiled by Whitfield and Baliwe (2014).

In view of the efforts expended over the past two decades in classifying South African estuaries for conservation and management purposes, the aim of presenting this historical, hitherto unpublished but in parts frequently cited, dataset is to provide a synoptic physical baseline (i.e., hydrological, morphological and sedimentological) against which more recent and future studies of the Breede River estuary can be compared. The dataset deals with the situation that existed in the summer season of 1983 .

\section{Study area}

The Breede River catchment lies in the winter rainfall region of the southern Cape Province, the river discharging into San Sebastian Bay just north of Cape Infanta, which is located about $94 \mathrm{~km}$ northeast of Cape Agulhas, the southernmost tip of Africa (Fig. 1). The estuary mouth, located at $34^{\circ} 24.483^{\prime} \mathrm{S} / 20^{\circ} 50.833^{\prime} \mathrm{E}$, is permanently open to the sea, though partly fronted by a wave-built sand bar (Fig. 2). The length of the Breede River from source to mouth is variably reported to be $293 \mathrm{~km}$ (Carter 1983) or $322 \mathrm{~km}$ (Lamberth et al. 2008). It has its source in the quartzites and sandstones of the Cape Fold Belt (Hex River, Langeberg and Riviersonderend mountains), the rocks belonging to the Table Mountain Group (Cape Supergroup), which is of Ordovician age (Thamm and Johnson 2006).

One of the earliest reports mentioning the lower Breede River in a geological context dates back to 1919 in a discussion of the coastal limestones of the Cape Province (Wybergh 1919). The Breede is one of several rivers between the Gouritz River and Cape Agulhas that dissect the so-called Bredasdorp Limestone, which is composed of laterally extensive coastal aeolianite ridges of late Tertiary to Quaternary age. They consist of variable mixtures of siliciclastic and bioclastic coastal sediments which have been cemented by dissolved and reprecipitated $\mathrm{CaCO}_{3}$, to the point of locally presenting a karst-like character (Marker 1981, 1988). The ridges overlie thick shale sequences of the Lower to Middle Devonian Bokkeveld Group (Cape Supergroup), which forms the base 
Fig. 1 Geographic location of the Breede River estuary (southern Cape Province, South Africa)

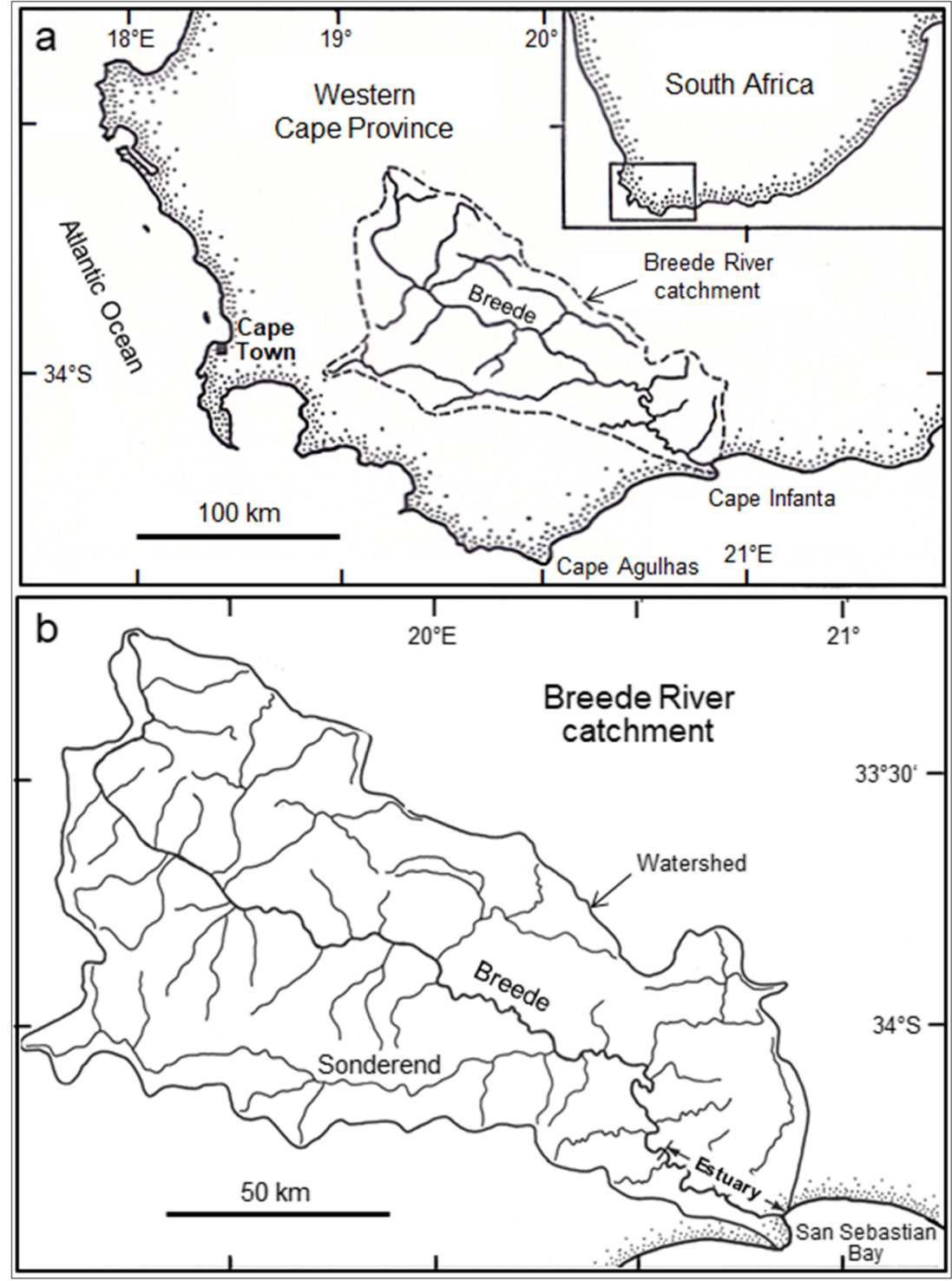

of the lower Breede catchment (cf. le Roux 1990, for a stratigraphic discussion). Relative to the present sea level, the modern estuarine river valley of the Breede River is deeply incised $(>50 \mathrm{~m})$ into the shales of the Bokkeveld Group. During Pleistocene sea-level lowstands the narrow, canyonlike incision probably exceeded $100 \mathrm{~m}$ locally. Late Quaternary sea-level fluctuations around southern Africa and general aspects of Holocene infilling of river valleys incised during Pleistocene sea-level lowstands are discussed in de Lecea et al. (2016).

According to Midgley and Pitman (1969), the Breede River drains a catchment area of $12,625 \mathrm{~km}^{2}$ (cf. also Taljaard 2003). More recent estimates of the catchment area vary from $12,384 \mathrm{~km}^{2}$ (CSIR 1987) to $12,385 \mathrm{~km}^{2}$ (Pitman et al. 1982), $12,587 \mathrm{~km}^{2}$ (Noble and Hemens 1978) and $12,596 \mathrm{~km}^{2}$ (DWA 1986). Similar discrepancies are reported for the mean annual runoff, Carter (1983) citing $1112 \times 10^{6} \mathrm{~m}^{3}$ for the period from 1966-1981, Noble and Hemens (1978) a pre1978 runoff of $1893 \times 10^{6} \mathrm{~m}^{3}$ and Taljaard (2003) a pre1990 runoff of $1784 \times 10^{6} \mathrm{~m}^{3}$. The different values probably reflect averages over different time periods. It is of interest to note that the mean annual runoff of the Breede River is the fourth highest of South African rivers. Based on the sediment yield map of Rooseboom (1978), the average annual sediment yield of the Breede River catchment has been estimated at $3.085 \times 10^{6}$ tons (G. Birch, Council for Geoscience, personal communication 1986), which corresponds to $2.057 \times 10^{6} \mathrm{~m}^{3}$. The CSIR (1987), by contrast, came to $\sim 2.384 \times 10^{6}$ t/year, which amounts to $1.589 \times 10^{6} \mathrm{~m}^{3} /$ year. The conversion from mass (tons) to volume $\left(\mathrm{m}^{3}\right)$ is based on a dry bulk density of $1.5 \mathrm{t} / \mathrm{m}^{3}$ (cf. Flemming and Hay 1984; Flemming and Delafontaine 2016).

The estuarine section of the river, i.e., that part of the lower river affected by the ocean tides, and which corresponds to the 


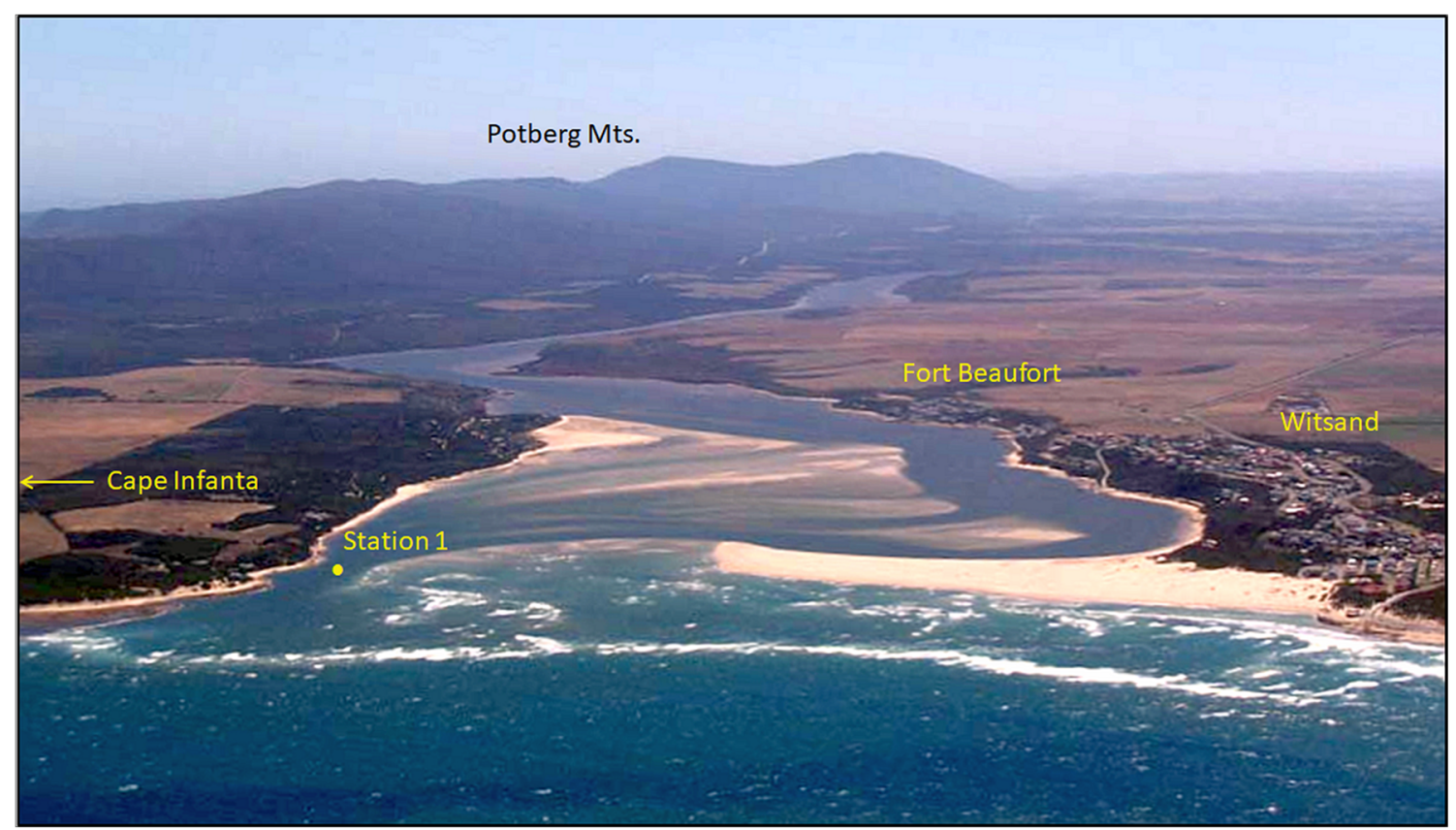

Fig. 2 Birds eye view of the funnel-shaped lower section of the Breede River. Note the size and orientation of the mouth bar and the large flood delta (view towards northwest). Also shown is the location of Station 1 in the middle of the main inlet channel at its narrowest width

upstream distance of tidal wave propagation, is variably reported to extend $50 \mathrm{~km}$ (Day 1981), $48 \mathrm{~km}$ (Scott and Scott 2001), or $52 \mathrm{~km}$ (Taljaard 2003) upstream from the mouth. For the purpose of the present study, the upstream limit of tidal wave propagation was taken to be $52 \mathrm{~km}$. Salt water intrusion, by contrast, varies greatly in dependence of coincidental river discharge and corresponds to the distance where the background salinity of the river water is reached (0.1-1.2; Carter 1983).

There is some uncertainty about the precise surface area of the estuary, Duvenage 1983 citing 835 hectares (ha) up to the $90^{\circ}$ bend ca. $18.5 \mathrm{~km}$ from the mouth, which corresponds to $8.35 \times 10^{6} \mathrm{~m}^{2}$ or $8.35 \mathrm{~km}^{2}$ (NB: the latter values have been misrepresented in Duvenage 1983). In contrast to this, Lamberth et al. (2008) cite an area of 445 ha for the estuary as a whole, which is clearly incorrect considering that an area of 1343 ha has been estimated in the present study on the basis of satellite imagery and which is in good general agreement with the areas of 1171 ha cited in the latest National Biodiversity Assessment (van Niekerk et al. 2019) or 1368 ha in the Botanical Database of the Nelson Mandela University, Port Elizabeth (Adams et al. 2016).

A detailed account of various environmental aspects of the wider, so-called Overberg region, which includes the Breede River estuary and its mostly ephemeral tributaries, is presented in Scott and Scott (2001). Additional scientific information can be found in Day (1981), Carter (1983), Duvenage (1983), de Villiers (1988), Taljaard (2003), and Lamberth et al. (2008). In this context, it should be noted that some of the data presented in several of the above studies were extracted from unpublished work of Flemming and Martin (1983), which forms the basis of the present paper.

\section{Materials and methods}

At the time of the survey, there was no tide gauge installed at the mouth of the Breede River. The theoretical daily tidal elevations for high and low water over a complete springneap-spring tidal cycle were therefore interpolated from the astronomical tide tables issued by the South African Hydrographic Office for Hermanus (located $\sim 186 \mathrm{~km}$ to the west) and Mossel Bay (located $\sim 130 \mathrm{~km}$ to the east), in proportion to the distance between the two locations (Fig. 3).

For the purpose of collecting hydrological, morphological, sedimentological, and physiographic data, the estuary was subdivided into sections spaced $1-1.5 \mathrm{~km}$ apart up to the Malgas ferry crossing at $\mathrm{km} 35$ (Fig. 4). The remaining $17 \mathrm{~km}$ of the estuary was not surveyed due to logistical limitations. Geographic coordinates were determined at midstream of each transect. These are listed in ESM Table S1 (ESM: Electronic Supplementary Material). In order to avoid confusion, it should be noted that, for the purpose of this study, the numbering of the transects has been reversed from that of Flemming and Martin (1983) and Carter (1983), i.e., instead of beginning with 1 a short distance downstream from the Malgas ferry crossing and ending with 36 at the mouth, the numbering begins at the mouth in the present study (Fig. $4 a, b)$. 
Fig. 3 Amplitudes of the semidiurnal tides for San Sebastian Bay (Breede River mouth) calculated by interpolation between the astronomical tides predicted for Hermanus and Mossel Bay over a spring-neap-spring tidal period (top) and integrated tidal ranges (bottom) for the month of December 1983 over the period in which the surveys took place

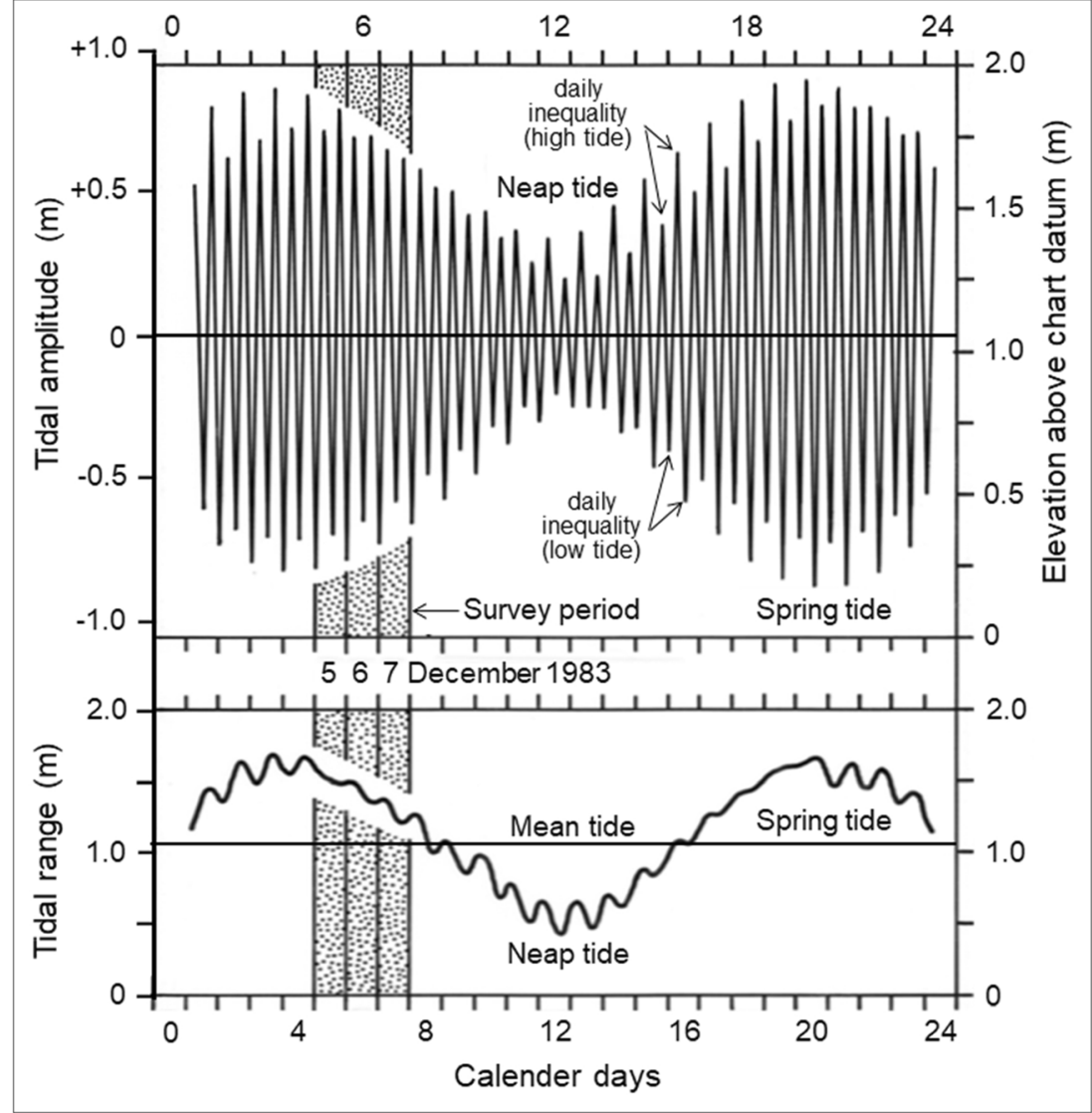

\section{Hydrological data collection}

Hydrological data were collected in December 1983 over complete tidal cycles (ca. $12 \mathrm{~h}$ ) at three midstream anchor stations at half-hourly intervals a few days after spring tide using a specially designed instrument package. The approximate geographic positions of the anchor stations (cf. Fig. 4) were $34^{\circ} 24.39^{\prime} \mathrm{S} / 20^{\circ} 50.83^{\prime} \mathrm{E}$ (Station 1: estuary mouth; cf. Fig. 2 for location), $34^{\circ} 22.90^{\prime} \mathrm{S} / 20^{\circ} 43.66^{\prime} \mathrm{E}$ (Station 2: $14.5 \mathrm{~km}$ upstream), and $34^{\circ} 20.64^{\prime} \mathrm{S} / 20^{\circ} 36.28^{\prime} \mathrm{E}$ (Station 3: $24 \mathrm{~km}$ upstream). The measured parameters comprised tidal elevation (derived from changes in water depth at the anchor stations), flow velocity (measured at 1-m depth intervals using a calibrated, in-house constructed Savonius-type analogue current metre, starting upward from $0.5 \mathrm{~m}$ above the bed, with the final reading being made just below the water surface), salinity (measured at the surface and $0.5 \mathrm{~m}$ above the bottom), temperature (measured at the surface and $0.5 \mathrm{~m}$ above the bottom), and light transmittance (measured $0.5 \mathrm{~m}$ below the surface on the shaded side of the boat and $0.5 \mathrm{~m}$ above the bottom). Due to the sluggish response of the current metre, the measured flow velocities do not represent instantaneous but rather time-integrated values read off after the needle of the display remained reasonably stable. At the time of the survey, the ebbing tide fell into the premidday hours and the flooding tide into the afternoons. Because of this, the ebb phase is presented before the flood phase in corresponding diagrams.

Tidal phase delays were determined at overall 10 locations along the estuary $(0 \mathrm{~km}, 5 \mathrm{~km}, 7 \mathrm{~km}, 10 \mathrm{~km}, 14.5 \mathrm{~km}, 20 \mathrm{~km}$, $24 \mathrm{~km}, 30 \mathrm{~km}$, and $35 \mathrm{~km}$ from the mouth), among them the three anchor stations $(0 \mathrm{~km}, 14.5 \mathrm{~km}, 24 \mathrm{~km})$. The tidal delay curves for both the flood and ebb tide initially increase gradually, reaching $\sim 10$ and $\sim 20$ min, respectively, at the landward limit of the lower estuary ( $\sim 5 \mathrm{~km}$ upstream from the mouth), before rising more steeply in almost linear fashion towards the limit of landward propagation.

\section{Turbidity measurements}

Light transmittance measurements were carried out using a digital readout instrument, model 269WA170 turbidity metre of the Kahl Scientific Instrument Corporation (KAHLSICO), El Cajon, California. The instrument measures the percent light transmittance across a set distance chosen on the basis of the overall turbidity, such that the highest turbidity (lowest light transmittance) could still be clearly distinguished. Using this setting, the instrument was calibrated in the laboratory using a concentrated sample of suspended mud from the estuary which was progressively diluted by known volumes of 
Fig. 4 Plan view of the Breede River estuary up to the Malgas ferry crossing ( $\mathrm{km} \mathrm{35}$ ) showing the location of hydrological stations, side-scan sonar profiles, bathymetric transects, and sampling stations (for technical details see Electronic

Supplementary Material). Note that the remaining $17 \mathrm{~km}$ of the estuary beyond $\mathrm{km} 35$ were not surveyed

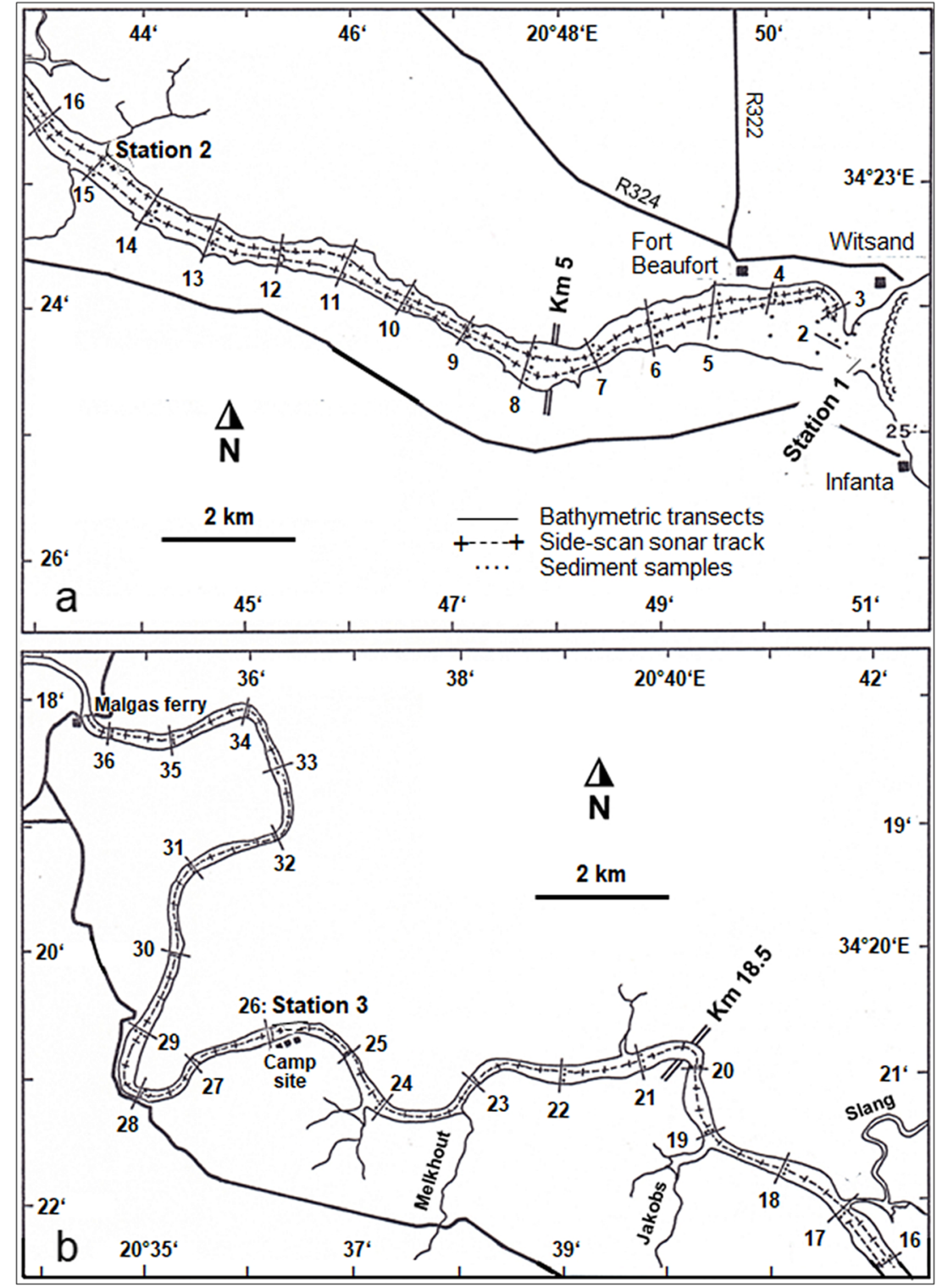

clean water under constant stirring, thereby generating overall 10 readings (Fig. 5). By application of the software programme TableCurve 2D (Systat Software Inc., San Jose, California), the light transmittance values were converted to suspended sediment concentrations (SSC) in milligrams per litre (mg/l) according to the equation:

$S S C=151.83-26.145 \ln (L T)$,

where $\ln$ signifies the natural logarithm and LT the light transmittance in \%; the coefficient of determination $\left(r^{2}\right)$ for this equation is 0.96 (cf. Fig. 5). It shows that the relation between light transmittance (\%) and suspended sediment concentration $(\mathrm{mg} / \mathrm{l})$ follows a tight logarithmic progression.

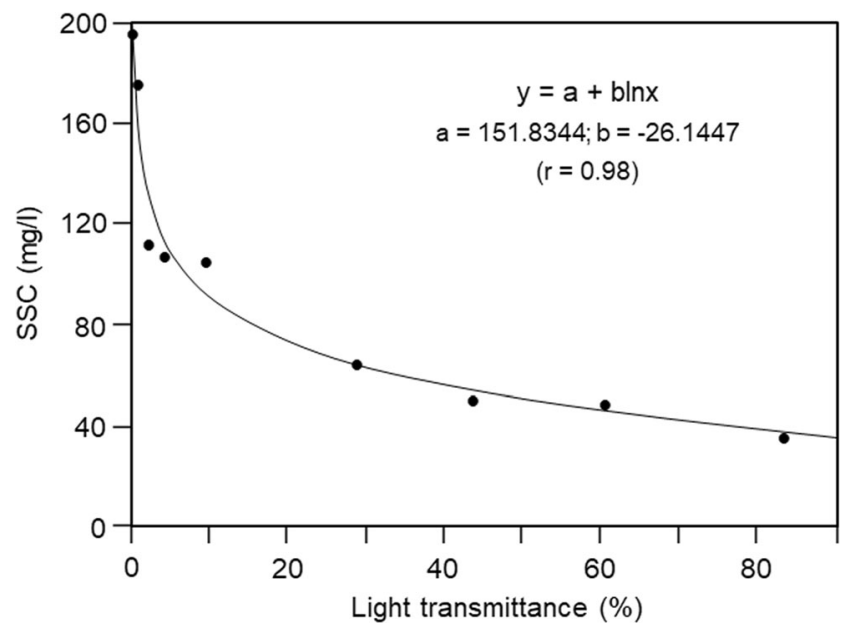

Fig. 5 Calibration curve showing suspended sediment concentrations (SSC) in $\mathrm{mg} / \mathrm{l}$ as a function of light transmittance (\%) 


\section{Morphological and physiographic surveys}

Starting at the estuary mouth, altogether 36 bathymetric transects were run across the estuary at $1-1.5-\mathrm{km}$ intervals using an analogue echo-sounder. The transect locations (cf. Fig. 4) were predetermined from a high-resolution topographic map, which also served navigation by means of specific, easily identified landmarks. The survey lines were aligned perpendicular to the two opposite embankments, the corresponding distances (river widths) being determined from the topographic map. In this way, the recorded widths on the analogue printout could be converted into true metric distances. While all depth profiles had the same vertical metric scale, the horizontal scales of the analogue records were slightly distorted due to small variations in the speed of the survey boat. These were normalized to a common metric scale in a postprocessing procedure by electronically stretching or compressing the scanned records, whichever the case was. On this basis, a comparative morphological analysis was made possible.

In addition to the bathymetric data, the estuary between the Malgas ferry crossing and the estuary mouth was surveyed by side-scan sonar using a 500-kHz Klein Hydroscan 520 system producing an analogue paper printout that was automatically marked every 2 min by event lines. The survey consisted of a single track along the centre of the narrow estuary section between transects T-36 and T-20, whereas two parallel tracks were run along the wider estuary between transect T-20 and the estuary mouth (cf. Fig. 4). As in the case of the bathymetric survey, the navigation in this case too oriented itself by landmarks identified on the topographic map. Besides recording physiographic features such as bedrock outcrops and current-induced bedforms (small dunes), the side-scan profile also revealed the occurrence of numerous, variably deep scour pools (depressions) in the bed. The precise geographic coordinates of their locations were retrospectively determined by zooming in on the estuary in Google Earth.

\section{Sediment sampling and grain-size analysis}

Overall, 105 surficial sediment samples were recovered from the river bed by means of a hand-deployed miniature van Veen grab-sampler along 35 of the 36 transects (cf. Fig. 4). In most cases, at least three samples were collected, one near the left embankment (facing downstream), one in the centre of the river, and one near the right embankment. Near the mouth, where the estuary widens, four or more samples were recovered at more or less evenly spaced intervals. In addition, a number of randomly placed samples were collected on the flood delta.

The moist sediment samples were stored in sealed plastic vials until further processing. In the laboratory, the samples were washed through a 63-micron sieve into a bowl using as little fresh water as possible. The turbid supernatant water was then decanted into large containers. This procedure was repeated several times until the remaining water was essentially clear. The containers were then left standing for several days until the mud had settled out completely. The clear supernatant water was then siphoned off and the settled mud with some remaining water emptied into preweighed porcelain bowls, which were placed overnight into an oven for drying at $50{ }^{\circ} \mathrm{C}$. Once the water had evaporated, the bowls were again weighed, the difference in weight being equated to the mud mass. The sand fractions were similarly dried and weighed. Subsequently, the two corresponding masses were in each case added together and the two fractions (sand, mud) expressed as percentages of the total mass. Grain-size distributions of the sand fractions were determined by settling tube (cf. Flemming and Thum 1978), whereby the settling velocity distributions were subsequently converted to equivalent settling diameter distributions at 0.1-phi-size intervals. Besides calculating textural parameters (mean grain size, sorting, skewness, kurtosis) on the basis of percentile statistics (Folk and Ward 1957), the grain-size data are also presented in the form of cumulative frequencies and grain-size frequency distributions. Individual full-phi sand fractions are addressed in terms of the Wentworth (1922) classification.

Carbonate contents were determined on preweighed sand subsamples by means of hydrochloric acid digestion. After effervescence ceased, the treated samples were washed, dried, and weighed. The difference in weight was equated to the carbonate content, which was subsequently converted to a weight-percentage. Although this procedure is the least accurate of several methods for carbonate determination (e.g., Carver 1971), it was considered adequate for the purpose of this study.

\section{Offshore seismic survey}

Numerous seismic lines were run across San Sebastian Bay in the course of a regional survey using an in-house constructed, multielectrode sparker sound source fed by a $500 \mathrm{~J}$ EG\&G power supply unit. The return signals were recorded by an 8 -element hydrophone array, processed by a receiver unit at bandpass filter settings of $400-600 \mathrm{~Hz}$, and then printed on paper using an EPC graphic recorder. Depths below seabed were subsequently converted manually from milliseconds to metres using a factor of 0.8 to account for the difference in sound velocity between seawater and unconsolidated sediment. The track lines were placed such so as to complement those of an earlier investigation (Birch 1980). The main purpose of the survey was to determine the Holocene thickness of the nearshore sand prism and, in particular, to detect the buried palaeo-valley of the Breede River occupied during Pleistocene sea-level lowstands. 


\section{Database}

All relevant technical data can be accessed in the Electronic Supplementary Material (ESM) attached separately. Thus, transect numbers, their geographic locations, distances from the mouth, water depths, and sample numbers are listed in ESM Table S1; river reach, tidal range, river width, and tidal volume at spring and neap tide in ESM Tables S2 and S3; parameters used to calculate river discharges, tidal prisms at spring, mean and neap tides, and discharge ratios between tidal prisms and fluvial discharges in ESM Table S4; regression equations for the reconstructed along-estuary hydrological trends in ESM Table S5; and, finally, textural sediment data in ESM Table S6.

\section{Results}

\section{Hydrological trends at the measuring stations}

The hydrological interpretations presented in this paper are primarily based on the measurements made at the three midstream anchor stations that were occupied for complete tidal cycles in each case. In some cases, these were complemented by additional spot observations at selected locations along the estuary. The five parameters recorded at each anchor station, i.e., tidal elevation, current velocity, salinity, temperature, and light transmittance/turbidity, are illustrated in Fig. 6a-c. The situation at the time of the survey (December 1983) was assumed to correspond to that of an average summer season in the period from 1966-1981 (cf. Carter 1983).

\section{Tidal elevation}

At Station 1 (estuary mouth), the occurrence of low and high tide, as determined from the observed tidal elevations, corresponded closely to the times predicted by the interpolated tide table. Due to the strong ebb current in the mouth, the anchor was unable to hold the boat in position during peak flow, causing it to slowly drift seaward into increasingly deeper water. The associated draw-down in the tidal elevation amounted to overall $1.25 \mathrm{~m}$ (cf. Fig. 6a). This had a marginal effect on the measurement of the vertical current profiles but did not affect the other parameters. At Station 2 (km 14.5) and Station $3(\mathrm{~km} 24)$, an increasing delay in the occurrence of low and high tide relative to that at the mouth was observed. The nature of these delays is dealt with further on.

A feature common to all three stations was a pronounced velocity asymmetry of the tides, which was revealed by phase delays between the times of low (high) water and corresponding slack water (turn of the tide). These delays were observed to decrease up-estuary, amounting to $92 \mathrm{~min}$ at low tide and $75 \mathrm{~min}$ at high tide at Station 1 (Fig. 6a), $65 \mathrm{~min}$ at low tide and $62 \mathrm{~min}$ at high tide at Station 2 (Fig. 6b), and $32 \mathrm{~min}$ at

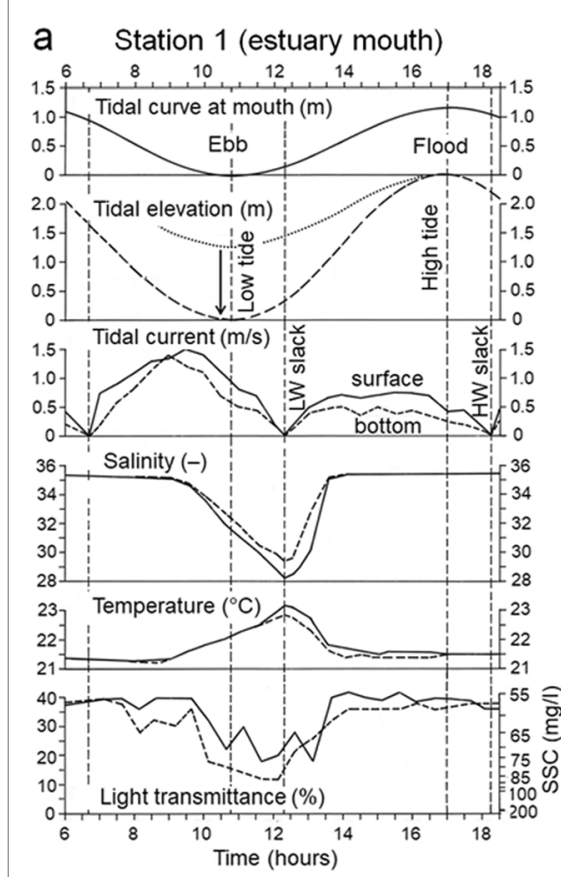

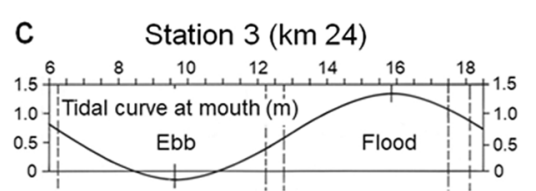
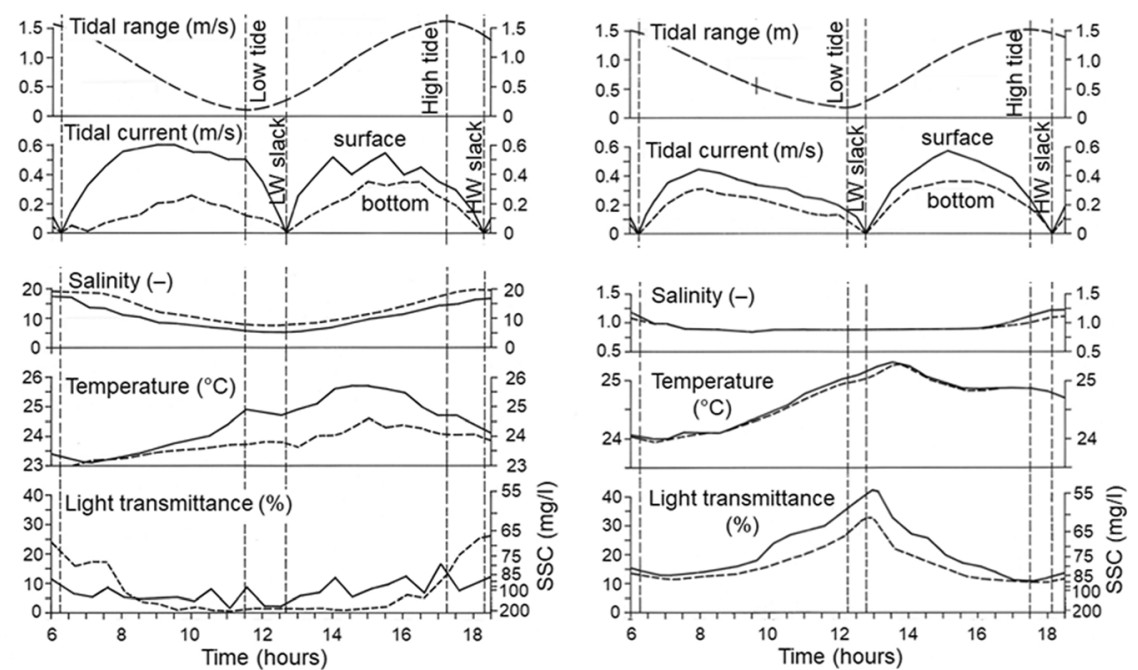

Fig. 6 Hydrological parameters recorded over full tidal cycles at the three measuring stations in the Breede River estuary. The measurements comprised time series of tidal elevations $(\mathrm{m})$, the tidal current velocity $(\mathrm{m} / \mathrm{s})$ at the surface and $0.5 \mathrm{~m}$ above the bottom, salinity at the surface and

$0.5 \mathrm{~m}$ above the bottom, water temperature $\left({ }^{\circ} \mathrm{C}\right)$ at the surface and $0.5 \mathrm{~m}$ above the bottom, and \%-light transmittance/turbidity $(\mathrm{mg} / \mathrm{l})$ at the surface and $0.5 \mathrm{~m}$ above the bottom 
low tide and $35 \mathrm{~min}$ at high tide at Station 3 (Fig. 6c). Of interest here is the progressive up-estuary decrease in the delay between low tide (high tide) and the turn of the tide in each case, amounting to $-17 \mathrm{~min}$ at Station $1,-3 \mathrm{~min}$ at Station 2, and $+3 \mathrm{~min}$ at Station 3, i.e., the delay reversed (increased) at high water upstream from about $\mathrm{km} 20$.

\section{Current velocity}

The strongest tidal current, both at the surface and $0.5 \mathrm{~m}$ above the bottom, was observed during the ebb phase at Station 1 (estuary mouth), where it reached $1.5 \mathrm{~m} / \mathrm{s}$ and $1.4 \mathrm{~m} / \mathrm{s}$, respectively. At Station 2, by contrast, the ebb current correspondingly reached peak velocities of only $0.6 \mathrm{~m} / \mathrm{s}$ and $0.25 \mathrm{~m} / \mathrm{s}$, while at Station 3 , it peaked at $0.45 \mathrm{~m} / \mathrm{s}$ and $0.3 \mathrm{~m} / \mathrm{s}$, respectively. Notable is the large difference between the surface and bottom current at Station 2. During the flood phase, the peak velocity at Station 1 reached $0.75 \mathrm{~m} / \mathrm{s}$ at the surface and $0.5 \mathrm{~m} /$ $\mathrm{s}$ at $0.5 \mathrm{~m}$ above the bottom, respectively. At Station 2, the corresponding velocities were $0.55 \mathrm{~m} / \mathrm{s}$ and $0.35 \mathrm{~m} / \mathrm{s}$, and at Station 3, respectively, $0.58 \mathrm{~m} / \mathrm{s}$ and $0.35 \mathrm{~m} / \mathrm{s}$. Notable here is that, at Stations 2 and 3, the peak current at the bottom was higher during the flood phase than during the ebb phase and that, at Station 3, the peak flood current at the surface even surpassed that of the peak ebb current. Thus, at the time of the survey (December 1983), the estuary beyond km 18.5 was in part distinctly flood dominated. As shown further down, this is documented by upstream directed bedload transport (revealed by the direction of bedform migration).

\section{Salinity}

As to be expected, salinity varied considerably not only with distance from the mouth but also with respect to the tidal phase. Thus, at the mouth (Station 1), the open ocean salinity of $\sim 35$ was maintained up to halfway through the ebb phase before progressively dropping to 28 at the surface and 29.5 at the bottom at low-water slack tide (Fig. 6a). With the onset of the flood tide the salinity increased rapidly, both at the surface and near the bottom, to again reach values $\sim 35$ for the rest of the tidal cycle. At Station 2 , by contrast, the salinity peaked at high-water slack tide, reaching 20 at the surface and $\sim 17$ near the bottom (Fig. 6b). Both values decreased gradually to reach lowest values of 6 and 8, respectively, between low tide and low-water slack tide. The trend then reversed in like manner towards the next high tide. A very similar trend was observed at Station 3 (Fig. 6c), except that the water column was now vertically homogenous at a salinity of $\sim 1$ throughout most of the tidal cycle, with exception of slightly raised salinities around high-water slack tide (1.25). The low value $(\sim 1)$ during most of the tidal cycle appeared to reflect the natural background salinity of the river water. This means that, at the time of the survey, the upstream limit of persistent salt intrusion was reached around $\mathrm{km} 25$. Overall, the salinity gradient between the water surface and the bottom was small, which is typical of well-mixed estuaries.

\section{Temperature}

The water temperature at the mouth (Station 1) showed an inverse trend to that of salinity, remaining almost constant at ca. $21.4{ }^{\circ} \mathrm{C}$ throughout the water column up to about halfway through the ebb phase before increasing gradually up to 23.2 ${ }^{\circ} \mathrm{C}$ at the surface and $22.7^{\circ} \mathrm{C}$ at the bottom towards low-water slack tide (Fig. 6a). With the onset of the flood tide, the temperature dropped rapidly to values around $21.5^{\circ} \mathrm{C}$ for the rest of the flood phase. At Station 2, the temperature development followed a very different trend to that at the mouth (Fig. 6b). Commencing with a temperature around $23{ }^{\circ} \mathrm{C}$, both at the surface and the bottom, it progressively increased across lowwater slack tide to reach $25.7^{\circ} \mathrm{C}$ at the surface and $24.5^{\circ} \mathrm{C}$ at the bottom halfway through the flood tide. From there, it gradually decreased to $\sim 24^{\circ} \mathrm{C}$, both at the surface and the bottom, at high-water slack tide. At Station 3, the temperature followed a similar trend to that at Station 2, except that it peaked at $25^{\circ} \mathrm{C}$, both at the surface and the bottom, shortly after lowwater slack tide (Fig. 6c), from where it gradually dropped to $24{ }^{\circ} \mathrm{C}$ throughout the water column towards high-water slack tide.

Although temperature fluctuations were overall small at all three stations $\left(\max .2 .7^{\circ} \mathrm{C}\right)$, the trends at the individual stations were quite distinct. The trend at the mouth can be explained by the mixing between colder seawater and warmer river water, highest values - as to be expected — being reached around low-water slack tide. At Stations 2 and 3, by contrast, highest values were reached during the flood phase, which could indicate an influence of rising air temperatures in the course of the day, keeping in mind that the survey was carried out in the southern summer (December). However, this does not explain the distinct vertical temperature gradient $\left(1^{\circ} \mathrm{C}\right)$ at Station 2. Possibly, it reflects a persistent influence of cooler seawater along the bottom of the estuary. At Station 3, the temperature trend appeared to mainly reflect the daily course in summer, the water heating up during the day and cooling off during the night.

\section{Light transmittance (turbidity)}

When assessing the temporal development of light transmittance, it should be noted that the linear scale on the left side of the corresponding diagram represents light transmittance (\%), whereas the logarithmic scale on the right side represents suspended sediment concentration (SSC) in $\mathrm{mg} / \mathrm{l}$ calculated on the basis of Eq. 1. The following description of the observed trends follows the temporal development of SSC (turbidity) over the tidal cycle. 
At the mouth (Station 1), the SSC remained low $(\sim 55 \mathrm{mg} / \mathrm{l})$ for the first $3 \mathrm{~h}$ of the ebb phase, i.e., up to the time when the flow peaked (Fig. 6a). Commensurate with the onset of decelerating flow the SSC increased rapidly to reach a maximum of $\sim 74 \mathrm{mg} / \mathrm{l}$ around low-water slack tide. About $1 \mathrm{~h}$ later, i.e., with the increasing influx of ocean water, it decreased just as rapidly to again reach $\sim 55 \mathrm{mg} / \mathrm{l}$, remaining at that level for the rest of the flood tide. The trend at the bottom was similar, except that the onset of increasing SSC occurred about $2 \mathrm{~h}$ earlier than at the surface and that the maximum concentration at low-water slack tide was higher $(\sim 87 \mathrm{mg} / \mathrm{l})$.

At Station 2, the SSC was overall higher than at the mouth, commencing at high-water slack tide with $\sim 92 \mathrm{mg} / \mathrm{l}$ at the surface and $\sim 68 \mathrm{mg} / \mathrm{l}$ at the bottom (Fig. 6b). The SSC then gradually increased both at the surface and the bottom in a flat $\mathrm{u}$-shaped curve to attain a maximum concentration of $\sim 200$ $\mathrm{mg} / \mathrm{l}$ around low-water slack tide, both at the surface and the bottom. The trend then reversed in like manner to reach similarly low values at the next high-water slack tide $(\sim 88 \mathrm{mg} / \mathrm{l}$ at the surface and $\sim 67 \mathrm{mg} / \mathrm{l}$ at the bottom). Notable here is the observation that in the $1-\mathrm{h}$ period between high water and the turn of the tide, the SSC was higher at the surface than at the bottom and that the overall highest SSCs (turbidity maxima) evidently occurred along the mixed sand/mud reach of the estuary.

At Station 3, the SSC followed an inverse trend to that observed at the other two stations (Fig. 6c). Highest concentrations ( $\sim 90 \mathrm{mg} / \mathrm{l}$ at both the surface and the bottom) occurred at high-water slack tide, from where the SSC progressively decreased to reach minimum values at the surface $(\sim 55 \mathrm{mg} / \mathrm{l})$ and the bottom $(\sim 60 \mathrm{mg} / \mathrm{l})$ shortly after low-water slack tide. The trend then reversed in like manner towards the next highwater slack tide.

\section{Vertical velocity profiles}

Vertical velocity profiles were measured at about half-hourly intervals over complete tidal cycles. Depending on the situation, between 10 and 13 profiles were acquired in each case. In their presentation, the accelerating (top panels of the diagrams) and decelerating (bottom panels of the diagrams) current phases of both the ebb current (left side of the diagrams) and the flood current (right side of the diagrams) are distinguished (Figs. 7-9).

Station 1 (estuary mouth): The most pronounced feature of the velocity profiles at the mouth is the marked difference in the peak velocities of the ebb and flood current, respectively (Fig. 7). As already indicated by the time series in Fig. 6, this is probably mostly due to the pronounced time/velocity asymmetry between the two tides, but different pathways of the peak flows of the flooding and ebbing tides may have been a contributing factor. Such flow separation is not uncommon in the mouth regions of estuaries where the locations of ebbdeltas and flood-deltas control the flow paths of the two opposing currents. The much higher velocities at the mouth in comparison to those at Station 2, for example, are explained by the much narrower channel cross-section, which causes a pronounced acceleration of the current. Another feature of interest is the rather erratic velocity fluctuation above the depth-averaged level, which suggests higher turbulence in that part of the water column. This can be explained by the observed penetration of ocean swells into the inlet. In the uppermost two metres, this may, in addition, have been augmented by turbulence generated around the boat. Overall, the slopes of the velocity profiles intimate a logarithmic shape only below the depth-averaged velocity level, the region above this level being evidently too turbulent for the type of instrument used. A clearer definition of the logarithmic nature of the velocity profiles would have required averaging instantaneous velocity measurements over several minutes at all measuring depths.

Station 2 (km 14.5): The velocity profiles at this location reveal two important features (Fig. 8). A first feature is the much flatter slope of the profiles during the ebb tide in comparison to the flood tide. As a consequence, the peak surface velocity $(\sim 0.6 \mathrm{~m} / \mathrm{s})$ is very much stronger than the peak bottom velocity $(\sim 0.25 \mathrm{~m} / \mathrm{s})$. This applies to both the accelerating and decelerating flow phases. During the flood tide, the velocity profiles in both the accelerating and decelerating flow phases are steeper than those during the ebb tide. Of interest here is the fact that, although the peak surface velocity during the flood tide $(\sim 0.5 \mathrm{~m} / \mathrm{s})$ is lower than that of the ebb tide, the peak bottom velocity $(\sim 0.35 \mathrm{~m} / \mathrm{s})$ is markedly higher, i.e., the residual bottom current at this location is flood dominated for a substantial period of time. In addition, the logarithmic nature of the velocity profiles is more obvious here than at Station 1.

Station $3(\mathrm{~km} \mathrm{24})$ : The trend observed at Station 2 not only continues at this location ( $9.5 \mathrm{~km}$ farther upstream) but actually becomes more accentuated (Fig. 9). Thus, the peak flood velocities at both the surface $(\sim 0.5 \mathrm{~m} / \mathrm{s})$ and the bottom $(\sim 0.3$ $\mathrm{m} / \mathrm{s})$ are now stronger than those of the ebb tide $(\sim 0.4$ and 0.25 $\mathrm{m} / \mathrm{s}$, respectively). The estuary evidently became increasingly more flood dominated upstream from Station 2 due to an increasing time/velocity asymmetry between the two tidal phases.

\section{Along-estuary hydrological trends}

The observations at the three anchor stations together with some supplementary measurements at other locations were used to reconstruct some relevant hydrological trends along the length of the estuary, namely, tidal delay, tidal 
Fig. 7 Vertical velocity profiles $(\mathrm{m} / \mathrm{s})$ of the accelerating and decelerating flow for both the ebb and flood phases at Station 1 (estuary mouth) measured at halfhourly time intervals from 07h00-18h30 on 07 Dec 1983
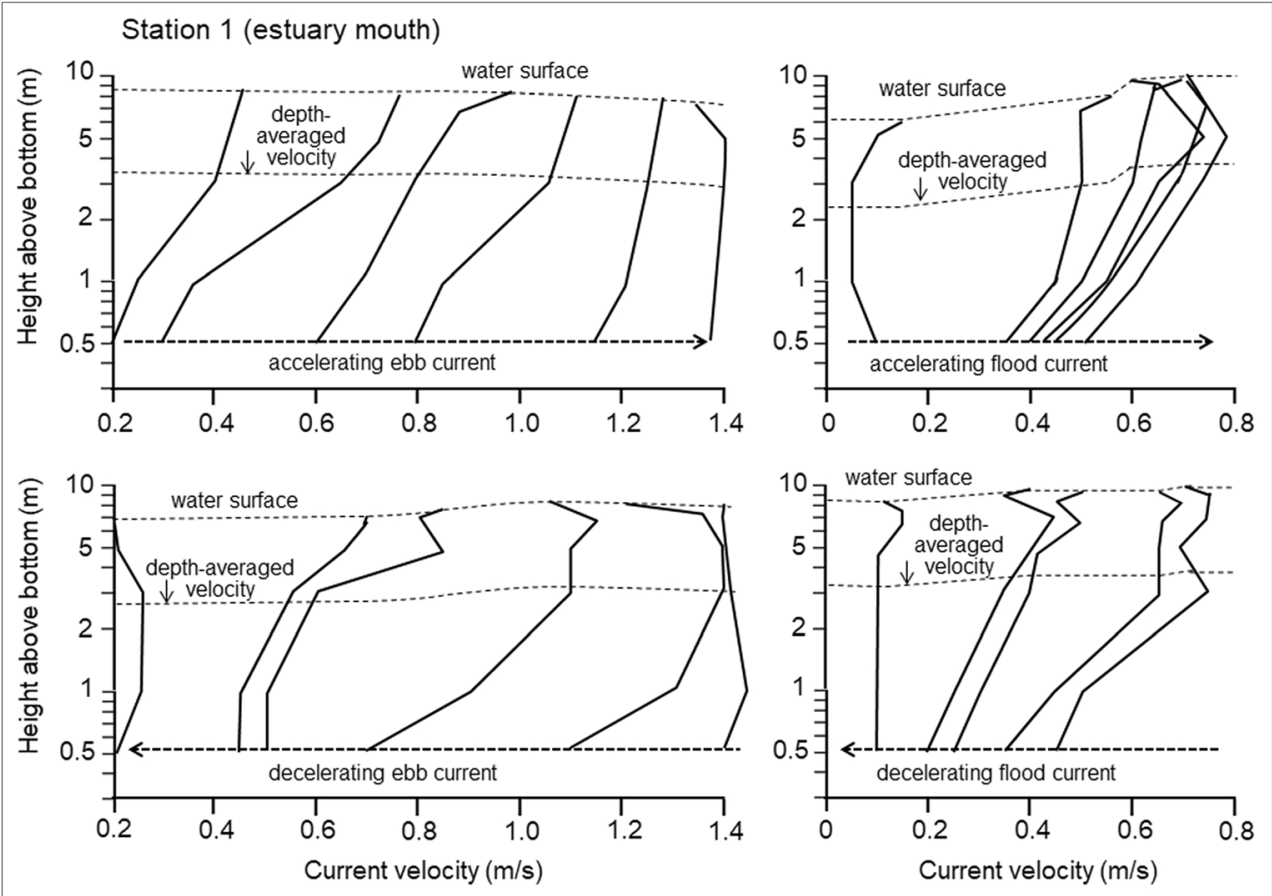

elevation, salinity, and light transmittance (turbidity). The reconstructed trends of these parameters as a function of distance from the mouth up to $\mathrm{km} 35$ are illustrated in Fig. 10. In all cases, they have been successfully subjected to regression analyses with coefficients of determination $\left(r^{2}\right)$ exceeding 0.99 . The corresponding regression equations are listed in ESM Table S5.
Fig. 8 Vertical velocity profiles $(\mathrm{m} / \mathrm{s})$ of the accelerating and decelerating flow for both the ebb and flood phases at Station $2(\mathrm{~km}$ 14.5: mixed sand/mud reach) measured at half-hourly time intervals from 06h30-18h00 06 Dec 1983

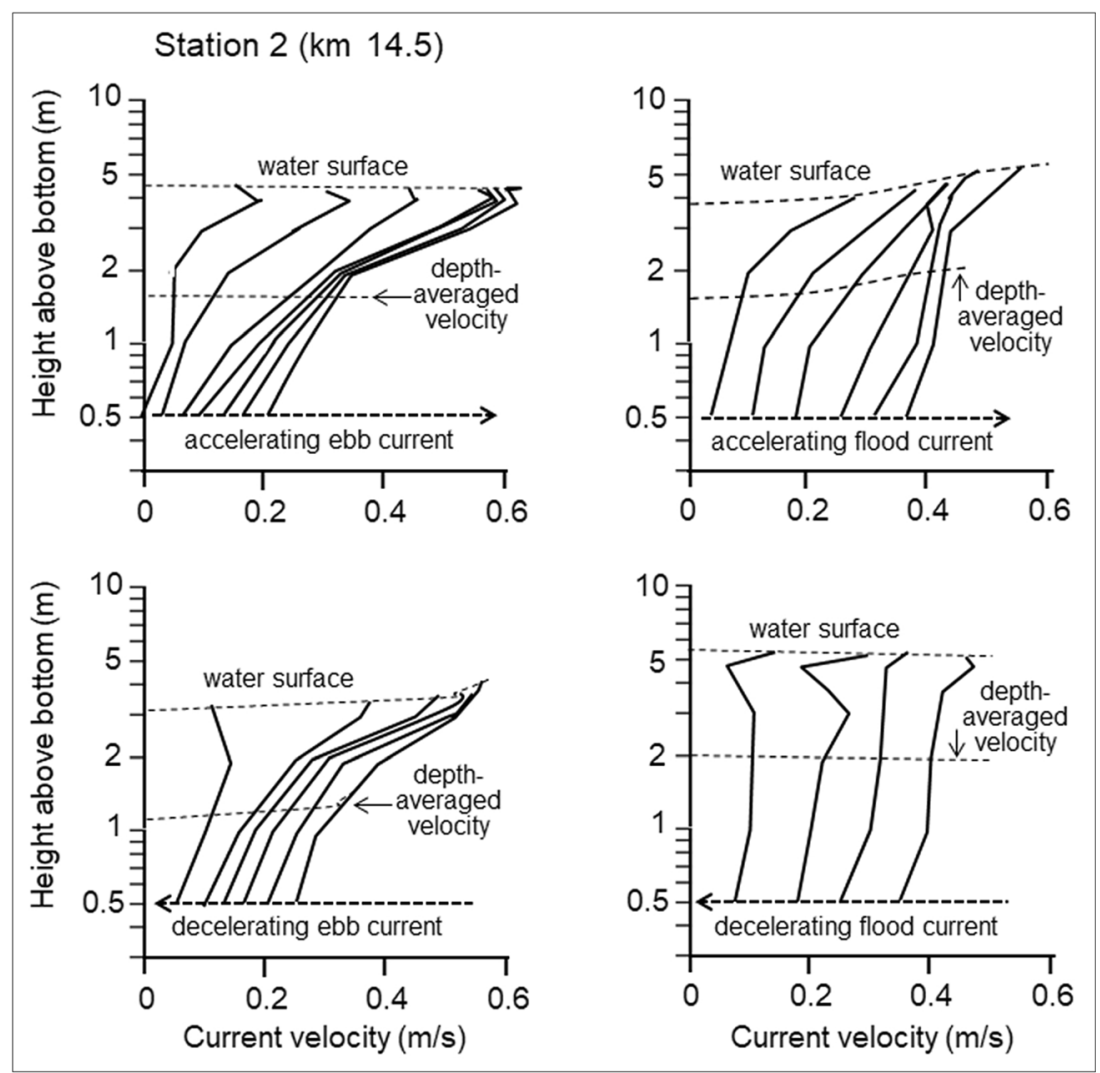


Fig. 9 Vertical velocity profiles $(\mathrm{m} / \mathrm{s})$ of the accelerating and decelerating flow for both the ebb and flood phases at Station $3(\mathrm{~km}$ 24: fluvial sand reach) measured at half-hourly time intervals from 06h30-18h00 on 05 Dec 1983

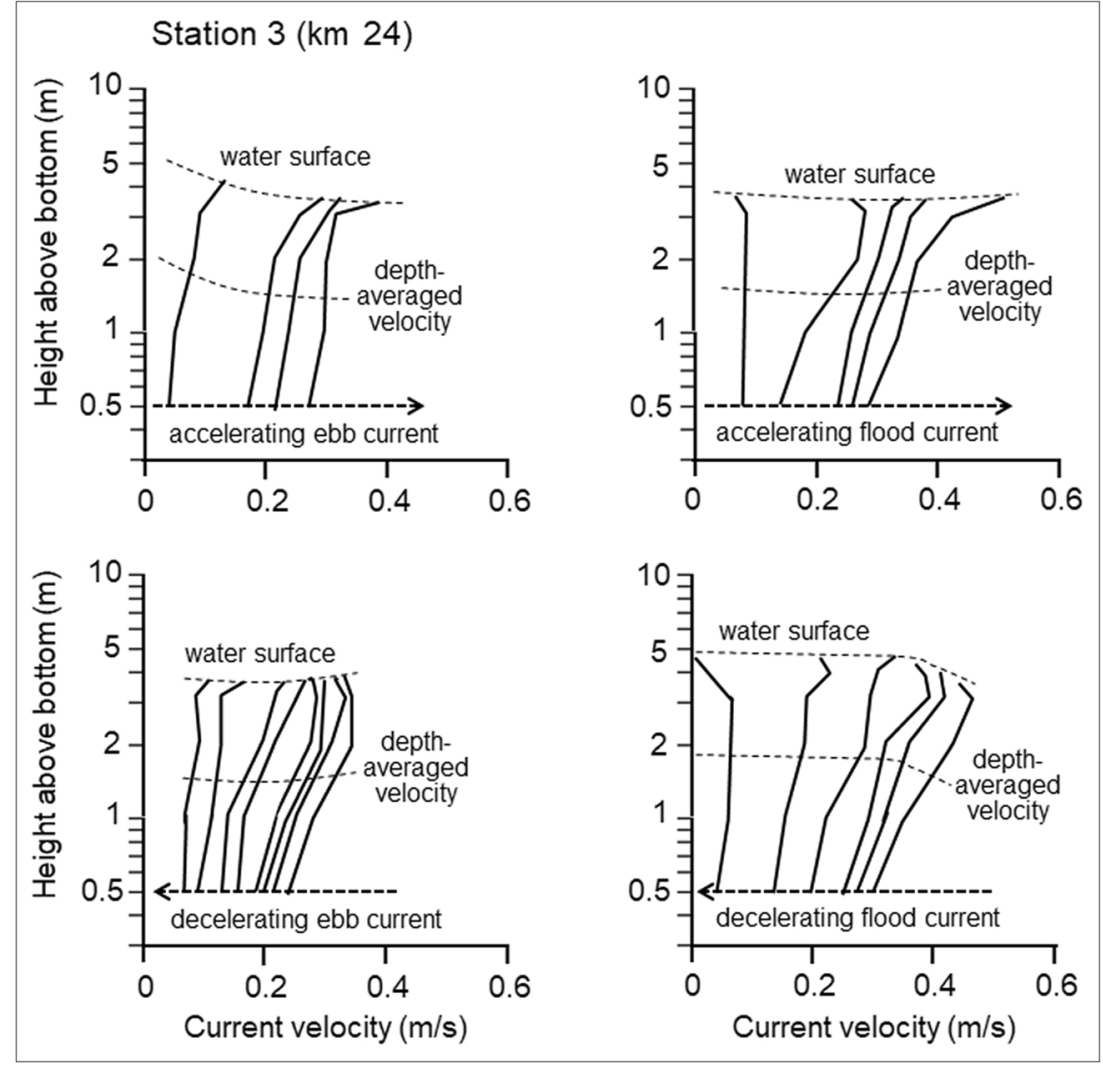

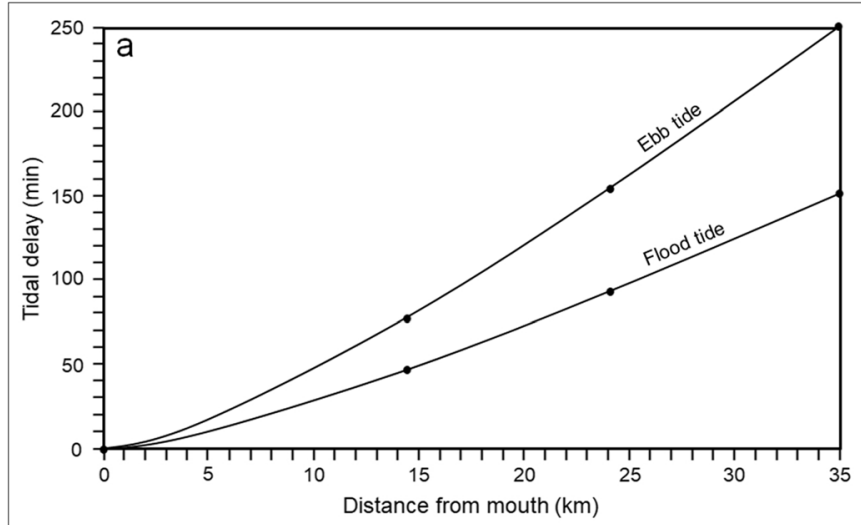
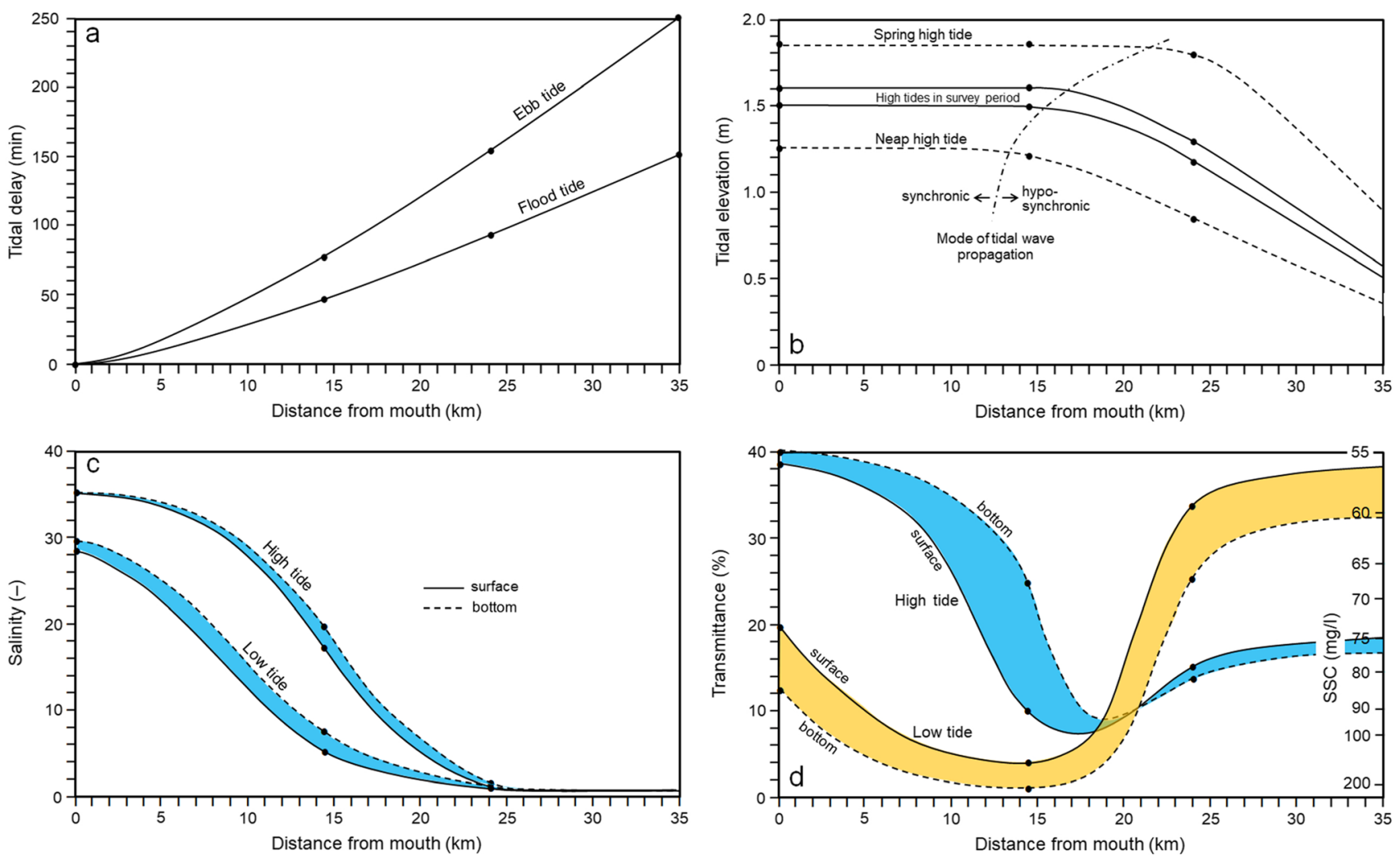

Fig. 10 Interpolated along-estuary hydrological trends between the mouth and the Malgas ferry crossing (km 35): (a) tidal delay (min); (b) tidal elevation (m); (c) salinity (-); (d) light transmittance (\%) and suspended sediment concentration (mg/l) 


\section{Tidal delay}

During the surveys, an up-estuary delay in the occurrence of both the ebb and the flood tide was observed. Initially, the delays increase gradually before adopting almost linear trends from about $\mathrm{km} 14.5$ onward towards the estuary head $52-\mathrm{km}$ upstream (Fig. 10a). The delay for the ebbing tide was observed to be substantially greater than that for the flooding tide, amounting to $7 \mathrm{~h}$ and $3 \mathrm{~min}$ at the estuary head $(\mathrm{km}$ 52), i.e., the subsequent flood tide entered the estuary mouth about 50 min before the low tide level was attained at the estuary head. The corresponding delay of the flooding tide at the estuary head, by contrast, amounted to only $4 \mathrm{~h}$ and 31 $\min$.

\section{Tidal elevation}

After entering the estuary mouth, the tidal wave initially progressed in synchronic mode (i.e., maintaining a constant elevation) for a considerable distance along the estuary. This applied to all tides from spring to neap (Fig. 10b). It continued in this mode up to about $\mathrm{km} 21$ at spring tide and up to about $\mathrm{km} 13$ at neap tide before adopting a hyposynchronic mode (i.e., progressive decrease in height) towards the estuary head. The synchronicity reflects the interplay between shoreline convergence, which causes the tidal range to increase, and friction along the river bed, which causes the tidal wave to slow down and the range to decrease in height. The synchronic mode thus indicates that convergence and friction were balanced, whereas the hyposynchronic mode signified a progressive dominance of friction over convergence.

From these trends, the tidal prisms for spring and neap tides were determined. They amounted to approximately $19 \times 10^{6}$ $\mathrm{m}^{3}$ on spring tides and $3.9 \times 10^{6} \mathrm{~m}^{3}$ on neap tides, the latter thus barely reached $20 \%$ of the spring tide volume. The large difference in volume is due to the pronounced difference in the potential ranges of the spring (ca. $1.8 \mathrm{~m}$ ) and neap tides (ca. $0.4 \mathrm{~m}$ ) entering the river mouth. To be noted here is that the measured maximum/minimum tidal elevations were in good general agreement with those predicted by the interpolated astronomical tidal curve which, in turn, suggests that, at the time of the observations, water levels were not noticeably influenced by other factors such as wind set-up/draw-down or water level variations caused by coastal trapped waves (cf. Schumann 2013).

\section{Salinity}

The salinity decreases progressively upstream from the mouth (Fig. 10c), both at high tide and at low tide, albeit starting from different values (high tide: $\sim 35$ at the surface and the bottom; low tide: $\sim 28$ at the surface, 29.5 at the bottom). Up-estuary the trends, both at high tide and low tide, as well as at the surface and the bottom, followed converging sigmoidal shapes to eventually meet at the background salinity of about 1 at $\mathrm{km} 25$. Salinities were marginally higher at the bottom along most of the estuary, both at high tide and low tide. For this reason, regressions were only calculated for the surface salinities at high and low tide.

\section{Turbidity}

In comparison to the other three parameters, the along-estuary trend of turbidity shows a more complex pattern (Fig. 10d). As to be expected, the lowest turbidity (SSC) is recorded at the mouth at high tide $(\sim 56 \mathrm{mg} / \mathrm{l}$ at the surface; $\sim 55 \mathrm{mg} / 1$ at the bottom) after the influx of open ocean water reaches its peak. From here, the turbidity increases progressively up-estuary in a sigmoidal trend until it reaches values around $100 \mathrm{mg} / \mathrm{l}$ at km 18.5. Notable is the fact that, at high tide, the turbidity was consistently lower at the bottom in comparison to the surface up to about $\mathrm{km} \mathrm{22}$. The maximum difference amounted to about $23 \mathrm{mg} / \mathrm{l}$ near Station 2 ( $\mathrm{km} \mathrm{14.5).} \mathrm{Upstream} \mathrm{of} \mathrm{km}$ 18.5 , by contrast, the turbidity decreased again and the vertical turbidity gradient reversed, highest values being now recorded at the bottom $(\sim 77 \mathrm{mg} / \mathrm{l})$, although the difference to the surface was not very large $(\sim 2 \mathrm{mg} / \mathrm{l})$.

Quite different was the trend observed at low tide. Starting at the estuary mouth with SSCs of $\sim 74 \mathrm{mg} / 1$ at the surface and $\sim 85 \mathrm{mg} / \mathrm{l}$ at the bottom, the turbidity increased progressively

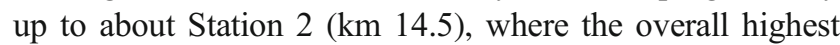
values were recorded at the bottom $(200 \mathrm{mg} / \mathrm{l})$. From here, the turbidity decreased rapidly up-estuary to reach its lowest low-tide value of $\sim 56 \mathrm{mg} / \mathrm{l}$ at the surface and $\sim 61 \mathrm{mg} / \mathrm{l}$ at the bottom at $\mathrm{km} 35$ and beyond. Notable is the distinct cross-over of the high-tide and low-tide trends between $\mathrm{km} 18.5$ and $\mathrm{km}$ 21 , i.e., around the upstream limit of the mixed sand/mud reach. Here, the SSC remained practically constant over the entire tidal cycle $(90-100 \mathrm{mg} / \mathrm{l})$, while the range increased both towards the head and the mouth of the estuary.

\section{Geomorphology and physiography}

The shape of the valley occupied by the Breede River estuary is relatively symmetrical, both banks (viewed downstream) rising steeply to $>50 \mathrm{~m}$ above topographic chart datum (approx. mean sea level) where it merges with the regional plateau formed by Bokkeveld shales. Small and narrow floodplains occur locally along both banks of the estuary. In plan view, the estuary shows distinct differences in sinuosity (sensu Mueller 1968) along the estuary (Fig. 4). Thus, up to the $90^{\circ}$ bend at $\mathrm{km} 18.5$ the sinuosity is low but increases markedly upstream from that landmark. This is probably an indication that, prior to incision into the bedrock, the palaeoBreede was a meandering river. 
Fig. 11 Selection of typical bathymetric river cross-sections characterizing the fluvial sand

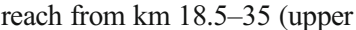
panel), the mixed sand/mud reach from $\mathrm{km} \mathrm{5-18.5} \mathrm{(middle} \mathrm{panel),}$ and the marine sand reach from the mouth to $\mathrm{km} 5$ (lower panel). Note the progressive widening of the estuary from head to mouth
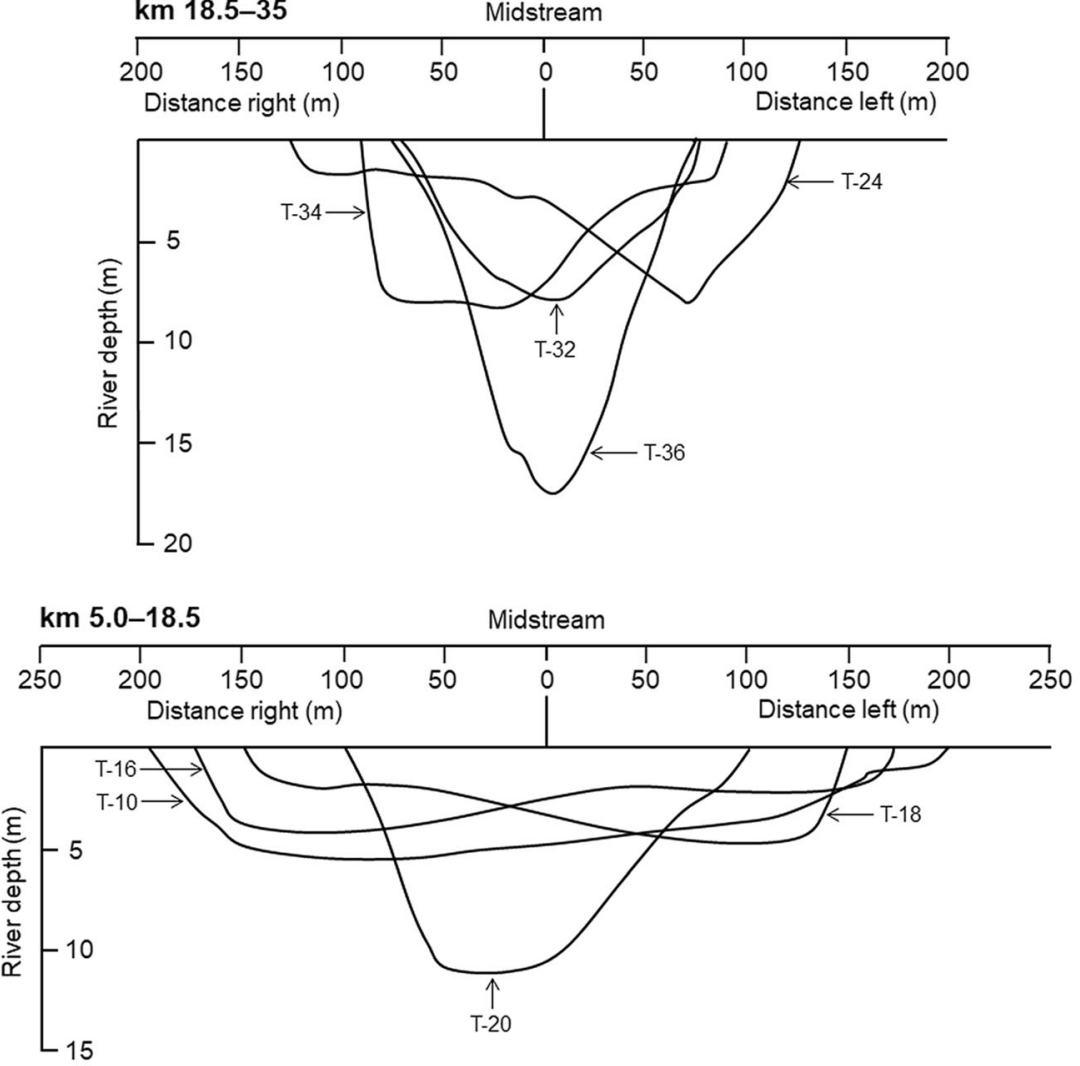

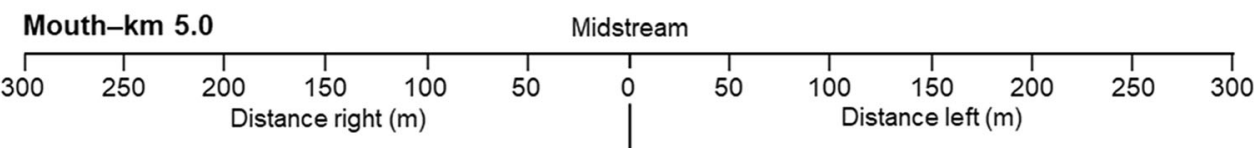

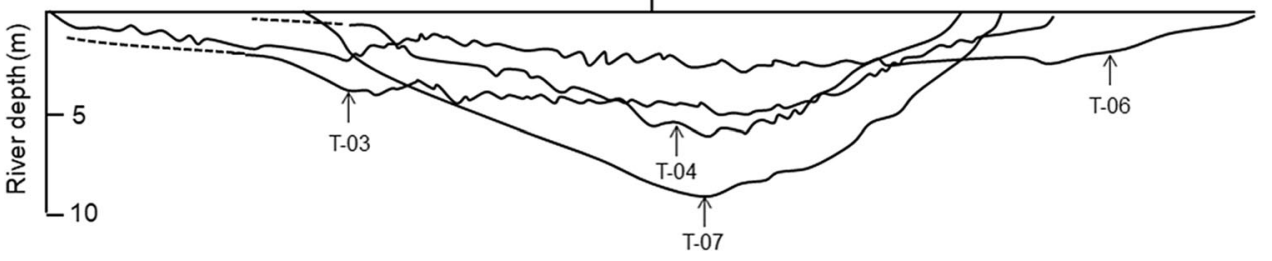

When considering the cross-sectional geometry, the estuary can be subdivided into three domains characterized by progressive downstream widening and shoaling of the river channel (Fig. 11). Thus, the maximum width and depth of the estuary upstream of $\mathrm{km} 18.5$ are $\sim 260 \mathrm{~m}$ and $\sim 18 \mathrm{~m}$, respectively, whereas the corresponding values are $\sim 400 \mathrm{~m}$ and $12 \mathrm{~m}$

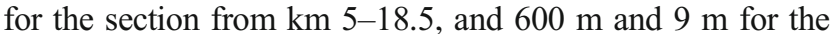
final section up to the estuary mouth. The maximum depths relate to those measured in scour pools (see below). Furthermore, the cross-sectional geometry of the estuarine channel is rarely symmetrical (e.g., transects T-36 and T-32 [Fig. 11, upper panel]) but is instead mostly skewed towards either the left or the right river bank (e.g., transects T-24 and T-34 [Fig. 11, upper panel] and transects T-18 and T-16 [Fig. 11, middle panel]). The cross-sectional geometry of the lower section (from $\mathrm{km} 5$ to the mouth) is by nature asymmetrical because of the large, partly intertidally exposed flood delta that is attached to the right river bank (viewed downstream towards the mouth). It takes up more than $60 \%$ of the funnelshaped area of this section, the remaining area being occupied by the ebb-dominated channel that hugs the left bank.

A particular feature of the estuary is the occurrence of deep scour pools (depressions) which are particularly frequent upstream from T-17 (off the Slang River confluence; cf. Fig. 4). Overall, 21 scour pools have been identified up to the Malgas ferry crossing, and more scour pools may exist beyond the ferry crossing not surveyed during this study. The deepest scours reach down to bedrock, as revealed by the rough backscatter signals in the sonographs of Fig. 12a, b. The axial pool lengths can reach several hundred metres, while depths vary from $3.5 \mathrm{~m}$ to at least $18 \mathrm{~m}$ (Figs 11, 12a, b; Table 1).

The sonographs also reveal the occurrences of flowtransverse bedforms (subaqueous dunes), their orientation being indicative of either ebb-dominance or flood-dominance of 
Table 1 Scour pools: locations, water depths, and orientation of bedforms

\begin{tabular}{|c|c|c|c|c|c|}
\hline \multirow{2}{*}{$\begin{array}{l}\text { Scour pool } \\
\text { number }\end{array}$} & \multirow{2}{*}{$\begin{array}{l}\text { Bathymetric transect } \\
\text { nr. }\end{array}$} & \multirow{2}{*}{$\begin{array}{l}\text { Side-scan depth } \\
\text { (m) }\end{array}$} & \multirow{2}{*}{$\begin{array}{l}\text { Bedform } \\
\text { orientation }\end{array}$} & \multicolumn{2}{|c|}{ Geographic coordinates } \\
\hline & & & & $\begin{array}{l}\text { Latitude } \\
\text { S }\end{array}$ & $\begin{array}{l}\text { Longitude } \\
\text { E }\end{array}$ \\
\hline 1 & $\mathrm{~T}-35-36$ & 15 & ebb & $34^{\circ} 18.16^{\prime}$ & $20^{\circ} 35.63^{\prime}$ \\
\hline 2 & $\mathrm{~T}-34-35$ & 3.5 & ebb & $34^{\circ} 18.08^{\prime}$ & $20^{\circ} 36.70^{\prime}$ \\
\hline 3 & T-33-34 & 11 & flood & $34^{\circ} 18.07^{\prime}$ & $20^{\circ} 37.02^{\prime}$ \\
\hline 4 & $\mathrm{~T}-33-34$ & 5 & flood & $34^{\circ} 18.18^{\prime}$ & $20^{\circ} 37.10$ \\
\hline 5 & $\mathrm{~T}-32$ & 7 & flood & $34^{\circ} 19.03^{\prime}$ & $20^{\circ} 37.23^{\prime}$ \\
\hline 6 & $\mathrm{~T}-31-32$ & 4 & flood & $34^{\circ} 19.08^{\prime}$ & $20^{\circ} 37.07^{\prime}$ \\
\hline 7 & $\mathrm{~T}-30-31$ & 9 & flood & $34^{\circ} 19.29^{\prime}$ & $20^{\circ} 36.25$ \\
\hline 8 & $\mathrm{~T}-30$ & 5.5 & flood & $34^{\circ} 19.48^{\prime}$ & $20^{\circ} 36.23^{\prime}$ \\
\hline 9 & T-29-30 & 7 & flood & $34^{\circ} 20.03^{\prime}$ & $20^{\circ} 36.23^{\prime}$ \\
\hline 10 & $\mathrm{~T}-28$ & 12 & flood & $34^{\circ} 21.08^{\prime}$ & $20^{\circ} 35.87^{\prime}$ \\
\hline 11 & $\mathrm{~T}-27$ & 9 & flood & $34^{\circ} 20.85^{\prime}$ & $20^{\circ} 36.42^{\prime}$ \\
\hline 12 & T-26-27 & 6 & flood & $34^{\circ} 20.77^{\prime}$ & $20^{\circ} 36.67^{\prime}$ \\
\hline 13 & $\mathrm{~T}-25$ & 8 & flood & $34^{\circ} 20.73^{\prime}$ & $20^{\circ} 37.82^{\prime}$ \\
\hline 14 & $\mathrm{~T}-24-25$ & 5.5 & flood & $34^{\circ} 20.92^{\prime}$ & $20^{\circ} 37.97^{\prime}$ \\
\hline 15 & T-23-24 & 7 & flood & $34^{\circ} 21.32^{\prime}$ & $20^{\circ} 38.35^{\prime}$ \\
\hline 16 & $\mathrm{~T}-23$ & 8 & flood & $34^{\circ} 21.17^{\prime}$ & $20^{\circ} 38.98^{\prime}$ \\
\hline 17 & T-22-23 & 14 & flood & $34^{\circ} 20.90^{\prime}$ & $20^{\circ} 39.33^{\prime}$ \\
\hline 18 & $\mathrm{~T}-20$ & 18 & flood/ebb ${ }^{\mathrm{a}}$ & $34^{\circ} 20.88^{\prime}$ & $20^{\circ} 41.23^{\prime}$ \\
\hline 19 & $\mathrm{~T}-18$ & 11 & symmetric & $34^{\circ} 21.43^{\prime}$ & $20^{\circ} 42.37^{\prime}$ \\
\hline 20 & T-18-19 & 8 & symmetric & $34^{\circ} 21.55^{\prime}$ & $20^{\circ} 41.47^{\prime}$ \\
\hline 21 & $\mathrm{~T}-17$ & 15 & ebb & $34^{\circ} 22.02^{\prime}$ & $20^{\circ} 42.62^{\prime}$ \\
\hline
\end{tabular}

${ }^{\text {a }}$ Flood-oriented on upstream side, ebb-oriented on downstream side of scour pool. the flow. Thus, on the sonograph of Fig. 12a, which corresponds to transect T-36 located a short distance downstream of the Malgas ferry crossing, the small dunes (height $\mathrm{H} \sim 1 \mathrm{~m}$, length $\mathrm{L} \sim 10 \mathrm{~m}$ ) face downstream to indicate ebb-dominance of the flow. By contrast, the dunes on the sonograph of Fig. 5b ( $\mathrm{H}$ mostly $<1 \mathrm{~m}, \mathrm{~L}$ mostly $<5 \mathrm{~m}$ ), located farther downstream between transects $\mathrm{T}-22$ and $\mathrm{T}-23$, face upstream to indicate flood-dominance. In fact, the side-scan sonar data reveal that between transects T-20 and T-34, the estuary was flood dominated at the time of the survey. As estuarine dunes migrate very slowly (a few $\mathrm{cm}$ per tide at most), they will not reverse during subsequent opposing tides but, instead, develop small ebb-caps or flood-caps that face in the opposite direction (e.g., Bartholomä et al. 2004; Ernstsen et al. 2005). Only at times of high river discharge will sediment transport, and hence bedform orientation, be uniformly directed downstream. The locations and depths of the scour pools, as well as the orientation of associated bedforms (flood or ebb), are listed in Table 1.

The physiography of the funnel-shaped estuary section downstream from $\mathrm{km} 5$ with its large flood delta is illustrated in Fig. 13. Here, the flow is split longitudinally into a flooddominated and an ebb-dominated channel section, the flood delta being obviously flood dominated, whereas the deep channel hugging the left bank is ebb dominated. Correspondingly, the bedforms here ( $\mathrm{H}$ up to $2 \mathrm{~m}$, $\mathrm{L}$ up to $50 \mathrm{~m}$ ) migrate in opposite and mutually evasive directions, as illustrated on the sonograph of Fig. 12c, which straddles the interface between the flood and ebb dominated sections. The opposing transport directions in this part of the estuary actually suggest the existence of a sand recirculation system.

Also of interest is the question of whether the flood delta has been subject to any substantial morphological changes in the course of time. To assess this, charts of 1865 and 1981 are compared with a satellite picture of 2019 (Fig. 13). The consistency in size and form of the flood delta over the past 154 years is indeed remarkable. This does not speak in favour of any substantial import/export of sand from/to the sea over this time period, keeping in mind that the chart of 1865 only shows the intertidally exposed part of the flood delta, whereas the images of 1981 and 2019 also show shallow subtidal parts. A comparison of the 1981 and 2019 images also reveals that the flood-delta is a dynamic environment characterized by continual, though small, changes in its topographic surface modulation. 
Fig. 12 Selected side-scan sonar images illustrating particular features. (a) 15-m-deep scour pool near Malgas ( $\mathrm{km} \mathrm{35}$; cf. Fig. 4) revealing exposed bedrock and ebb-oriented sand dunes. (b) 14m-deep scour pool near the camp site (km 14; cf. Fig. 4) showing bedrock outcrops and floodoriented sand dunes. (c) Apparent bedload parting revealed by sand dunes migrating in mutually evasive opposite directions ca. $2 \mathrm{~km}$ from the estuary mouth (cf. Fig. 4)
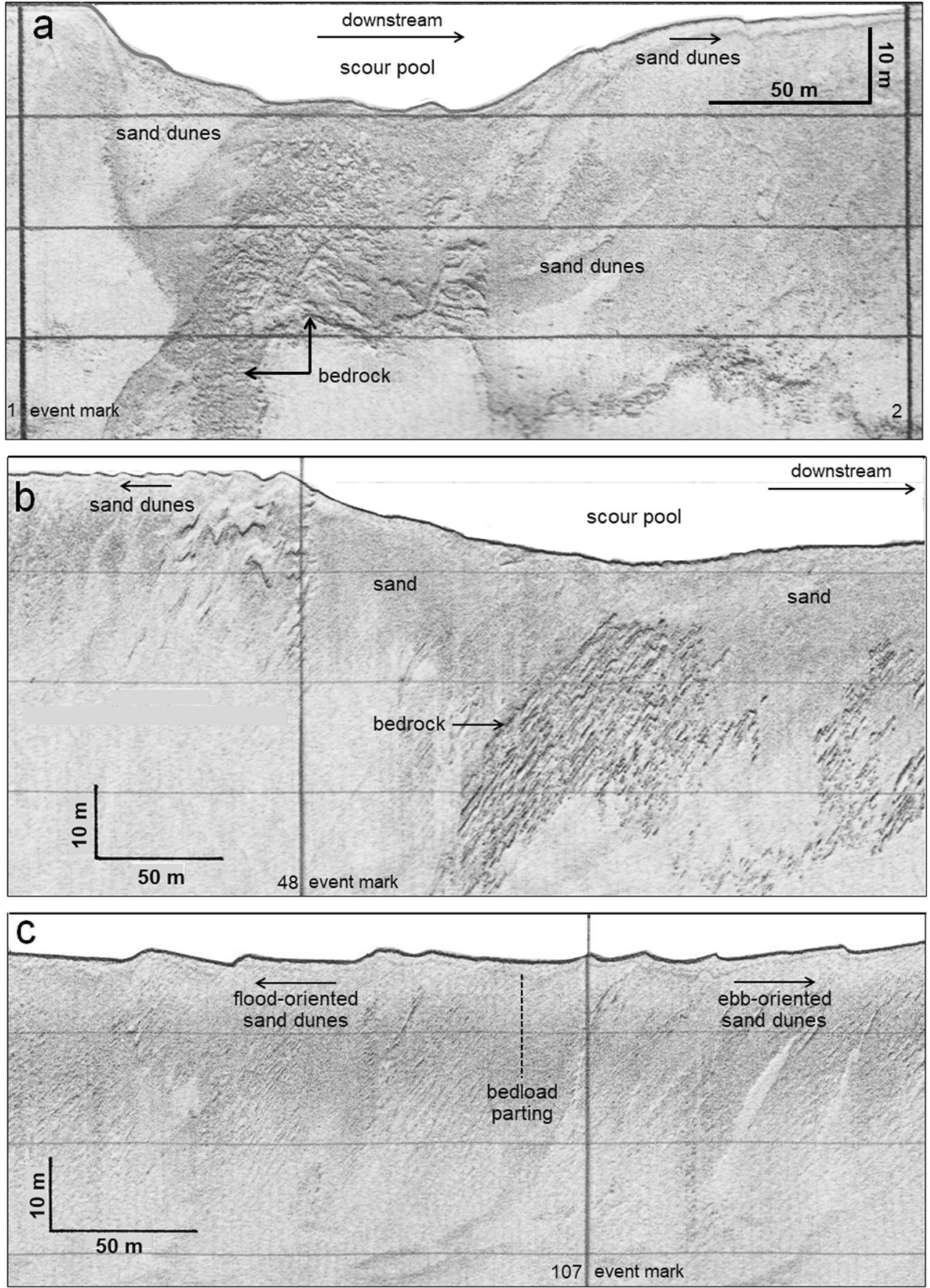

\section{Sedimentology}

To gain a general impression of sediment distribution along the length of the estuary up to $\mathrm{km} 35$, the mean diameters, sand/mud contents, and calcium carbonate $\left(\mathrm{CaCO}_{3}\right)$ contents of all mid-channel samples ( 35 of the overall 105) were plotted against distance from the mouth (Fig. 14). From a geological point of view, the combined sand, mud, and $\mathrm{CaCO}_{3}$ contents of the sediment clearly divide the main channel of the estuary into three domains, a marine sand reach up to $\mathrm{km} 5$

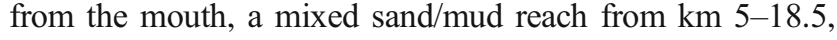
and a fluvial sand reach upstream from $\mathrm{km} \mathrm{18.5.} \mathrm{From} \mathrm{the}$ mouth to about $\mathrm{km} 3$ along the main channel, the mean diameter of the sand fraction ranges from 1.05 to $1.5 \mathrm{phi}(0.48-0.35$ $\mathrm{mm}$; medium sand). Thereafter, and up to the transition to the mixed sand/mud reach (at $\mathrm{km} \mathrm{5),} \mathrm{the} \mathrm{mean} \mathrm{grain} \mathrm{size} \mathrm{rapidly}$ fines, reaching minimum values of 2.4 phi $(0.19 \mathrm{~mm}$; fine sand). The average mean grain size of all mid-channel samples is 1.75 phi $(0.3 \mathrm{~mm}$; medium sand). 
Fig. 13 Plan views of the Breede River mouth and the flood delta of 1865,1981 , and 2019. The map of 1865 only shows the intertidal parts of the flood delta, whereas those of 1981 and 2019 also show subtidal parts. Note the remarkably consistent flood-delta shape over the 154-year period
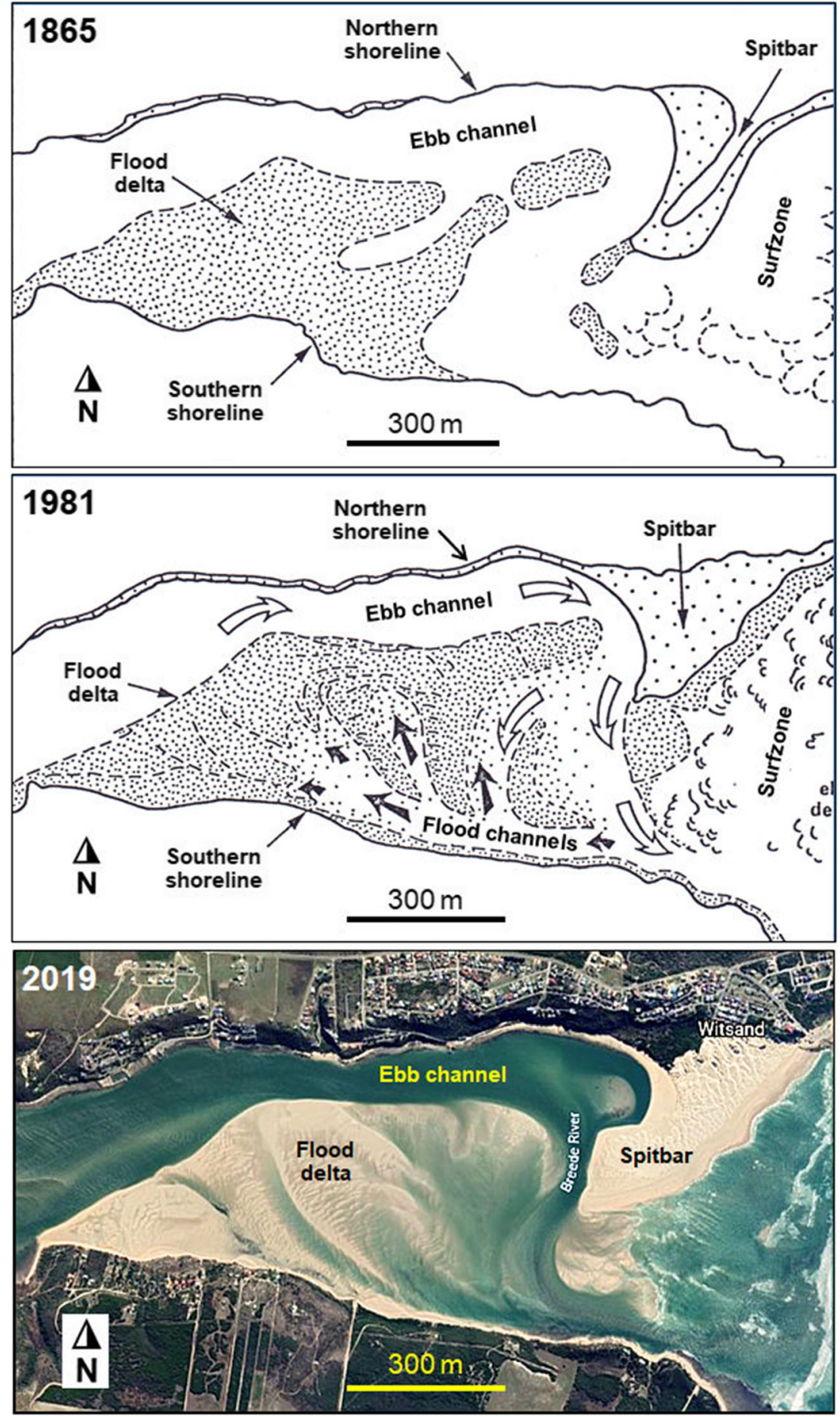

A point of particular interest here is the $\mathrm{CaCO}_{3}$ content, which progressively decreases from about $80 \%$ at the mouth to $0 \%$ at $\mathrm{km} 8$, the latter signifying the maximum distance of marine sediment influx. The mud content, by contrast, shows the opposite trend, progressively increasing from $<5 \%$ at the mouth to just over $40 \%$ at $\mathrm{km} 5$. From here up to $\mathrm{km} 18.5$, the mean grain size of the sand fraction fluctuates widely between $1.3 \mathrm{phi}(0.41 \mathrm{~mm}$; medium sand) and $2.4 \mathrm{phi}(0.19 \mathrm{~mm}$; fine sand). It is the estuarine section with the highest mud contents, which vary from 25 to $75 \%$ but are mostly $>50 \%$. Beyond $\mathrm{km}$ 18.5 , the estuary is characterized by high sand contents $(>90 \%)$ with mean diameters predominantly ranging from 1.7 to $2.3 \mathrm{phi}(0.31-0.2 \mathrm{~mm}$; fine to medium sand).

Of the overall 105 sediment samples, 22 came from the marine sand reach, 39 from the mixed sand/mud reach, and 44 from the fluvial sand reach (cf. ESM Tables S1 and S6). 


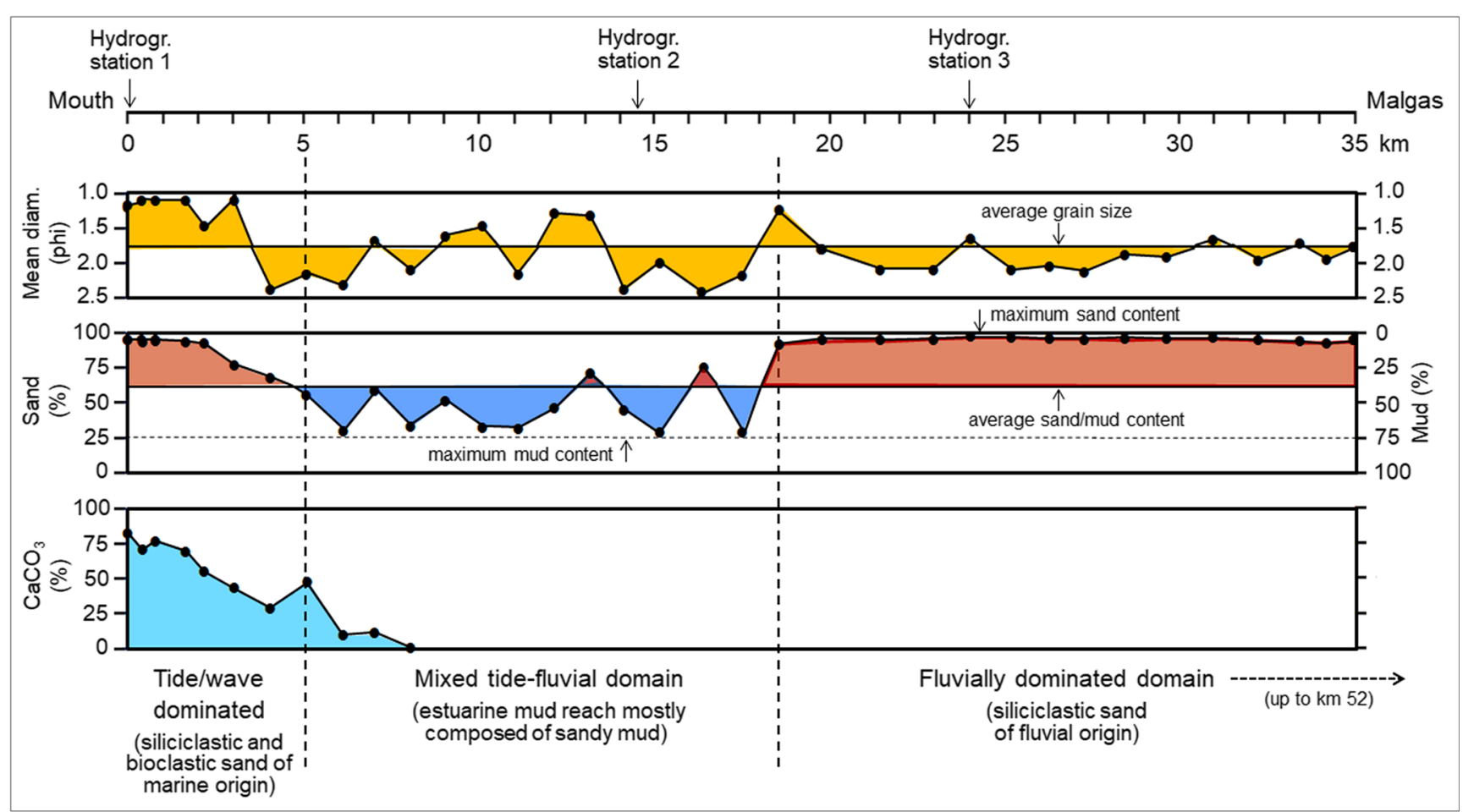

Fig. 14 Diagram illustrating the progression of mean grain size, sand/ mud content, and calcium carbonate content along the middle of the river channel between the estuary mouth and the Malgas ferry crossing $35-\mathrm{km}$ upstream. Also indicated are the locations of the measuring stations and

Particular grain-size trends were initially expected to be highlighted by the relationships between individual textural parameters (mean diameter, sorting, and skewness) to indicate either mixing or unmixing of hydraulic populations. Such scatter diagrams have yielded much useful information in other environments (e.g., Folk and Ward 1957; Flemming 1988). The plots, however, were inconclusive and did not reveal any consistent trends, except vaguely indicating mixing between different or size-sorting of individual grain-size populations.

More revealing are the corresponding grain-size frequency curves (both cumulative and grain-size frequencies), especially when grouped separately for the individual estuarine domains (Fig. 15). Cumulative frequencies (log-probability scaled along the ordinate) are displayed on the left side of Fig. 15, and the corresponding grain-size frequencies on the right side, in each case separately for each estuarine domain. Already at first glance the diagrams present a highly complex, though quite differentiated picture for each domain. In all three domains, the bedload sediment is characterized by at least four hydraulic populations, many of them unimodal, others bimodal or even multimodal. In addition, there appear to be some subordinate populations, especially in the fluvial domain of the estuary. The existence of several hydraulic populations is not unexpected considering the variety of depositional environments characterizing the sedimentary source rocks within the Breede catchment. the subdivision of the estuary into the marine sand reach (mouth- $\mathrm{km} \mathrm{5}$ ), the mixed sand/mud reach ( $\mathrm{km} \mathrm{5-18.5),} \mathrm{and} \mathrm{the} \mathrm{fluvial} \mathrm{sand} \mathrm{reach} \mathrm{up} \mathrm{to}$ $\mathrm{km} 35$

Beginning with the fluvial domain (Fig. 15, top panel), one can clearly distinguish a single well sorted, coarse-grained to very coarse-grained population (1), which also occurs as a subordinate component admixed into finer-grained populations. A second clearly defined population is composed of very fine sand (4) which has a fine tail that reveals the admixture of an even finer subordinate population. Finally, there is a large number (32) of very well sorted, overlapping mediumgrained to coarse-grained unimodal distributions which, in the cumulative plot on the left, are represented by the tight group of essentially straight sloping lines and, in the grain-size frequency curves on the right side, by the group of curves with modal diameters between 1.5 and 2.5 phi, the individual frequencies of which exceed $22 \%$. Some of these may be the outcome of progressive grain-size sorting (intimated by the down-sloping arrows), but this is not compelling.

The picture becomes clearer when viewing the frequency curves of the mixed sand/mud domain of the estuary (Fig. 15, middle panel). The predominance of sigmoidal shapes in the cumulative frequency plot on the left and modal diameters with frequencies $<18 \%$ on the right indicates that the majority of samples are now composed of mixtures between two or more grain-size populations. These can be divided into four groups, two of which (group 1 and 3) are characterized by progressive grain-size sorting (indicated by the downsloping arrows) which is revealed by the gradual fining of 

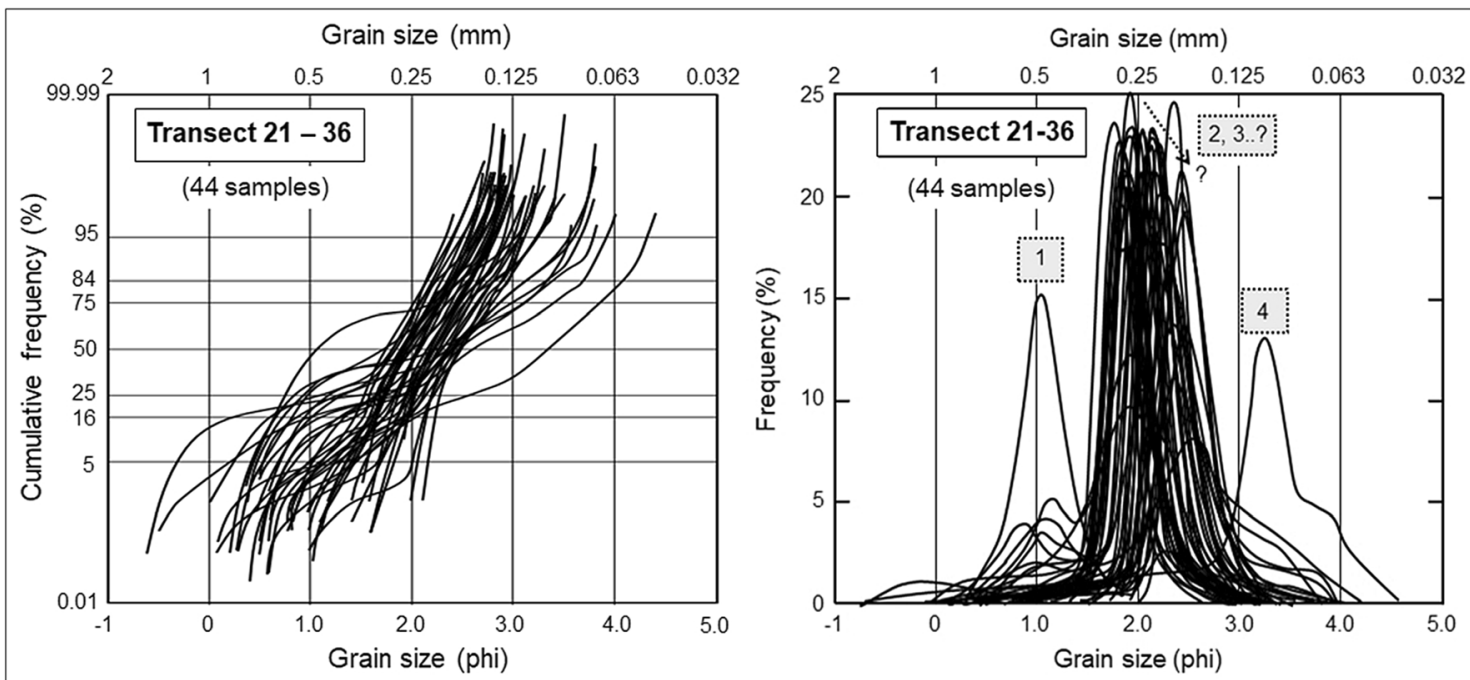

Grain size $(\mathrm{mm})$
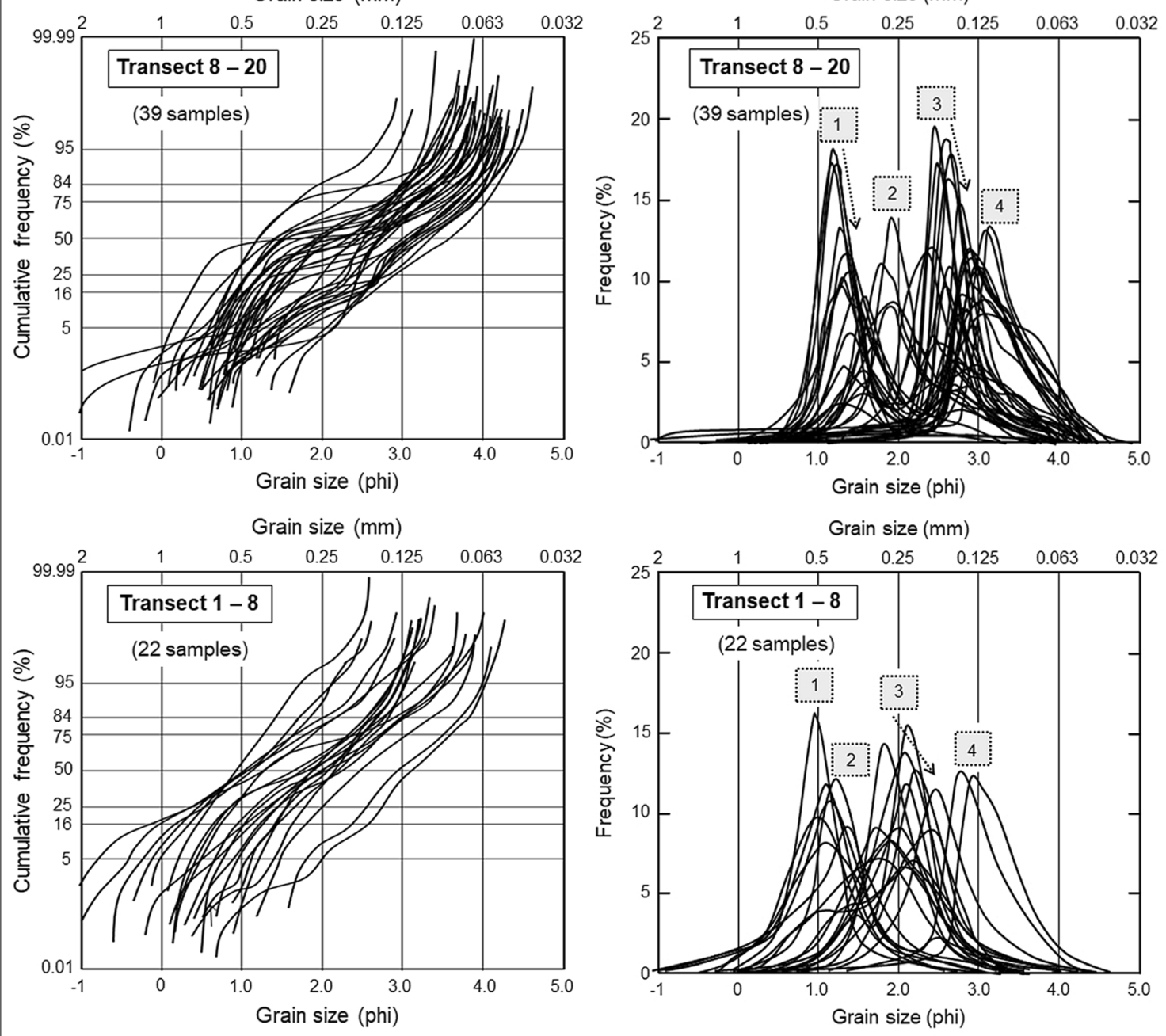

Fig. 15 Cumulative frequencies (left) and grain-size frequencies (right) of the three estuarine subdivisions as defined in Fig. 14. In particular, note the differences in the shapes and grouping characteristics of both the cumulative frequency curves (left side) and the grain-size frequency curves (right side)

corresponding modal diameters. Groups 2 and 4 , by contrast, remain more or less stable, their low frequencies suggesting multimodal mixtures that only vary in their proportional contribution to the total sediment. 
Finally, four populations also characterize the sediment of the marine sand domain (Fig. 15, bottom panel). Although the diameters of the modal grain sizes are similar to those of the middle estuary, they occur in overall lower proportions, which is indicative of poorer sorting due to mixing with neighbouring populations. It should be noted here that especially the coarser-grained samples are, in contrast to those of the other domains, composed of mixtures between siliciclastic and bioclastic sands of marine origin, the mixtures reaching ratios of 20:80 near the mouth.

\section{Holocene evolution}

Two sparker profiles illustrate the presence (Fig. 16a) and absence (Fig. 16b) of a Holocene sand cover. In the former case (Sparker profile a), the profile crosses the area above the buried Breede River palaeo-valley, revealing the existence of at least three parallel valleys which may either have been occupied simultaneously or sequentially by the river. The latter profile (Sparker profile b) is situated due south of the mouth of the Duiwenhoks River. It commences at the transition between the onlapping Holocene sand sheet to the left and the exposed bedrock surface extending towards the east and southeast. All seismic profiles located southeast of Sparker profile $b$ show the same exposed bedrock surface. Common to them is the distinct absence of an incised valley which could arguably represent the palaeo-valley of the Duiwenhoks River. From this, it is concluded that the Duiwenhoks must have been a tributary of the Breede during Pleistocene sea-level lowstands.

To reconstruct the course and visualize the landscape crossed by the Breede River during Pleistocene sea-level lowstands, the nearshore sand prism was stripped on the basis of the high-resolution seismic data. The scenario is schematically illustrated in the two block diagrams of Fig. 17 which show the modern setting at the top and the stripped palaeosituation at the bottom. Note the canyon-like incision of the Breede River near its present mouth during Pleistocene sealevel lowstands, and the confluence of the Duiwenhoks with the Breede before they together cross the Pleistocene 'Agulhas Plain'.
Fig. 16 Location of selected sparker seismic profiles from San Sebastian Bay. (a) Sparker profile a: Note the sediment cover and channels incised into the bedrock off the Breede River mouth. (b) Sparker profile b: Note the complete absence of a sediment cover and the lack of any channel incisions into the bedrock platform to the east of the Duiwenhoks River mouth

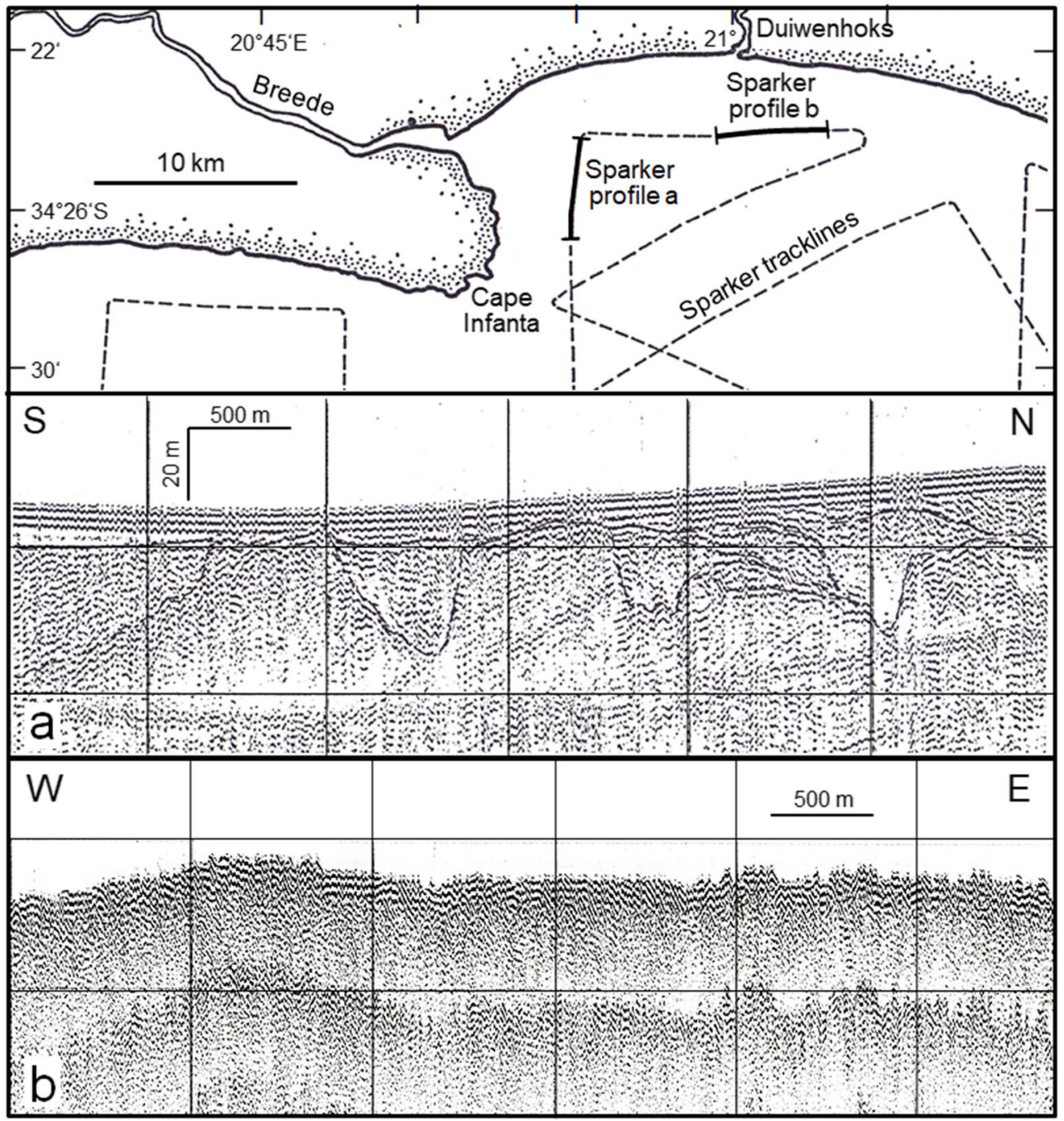


Fig. 17 Schematic threedimensional block diagrams representing the modern topography off Cape Infanta (top) and that of the same area during the last glacial maximum ( 18-ky BP) with the Holocene sediment cover removed (bottom). Note the split-up of the palaeo-Breede River into three channels at a depth of about $150 \mathrm{~m}$ below the present sea level, and the suggested confluence of the Duiwenhoks River with the Breede River
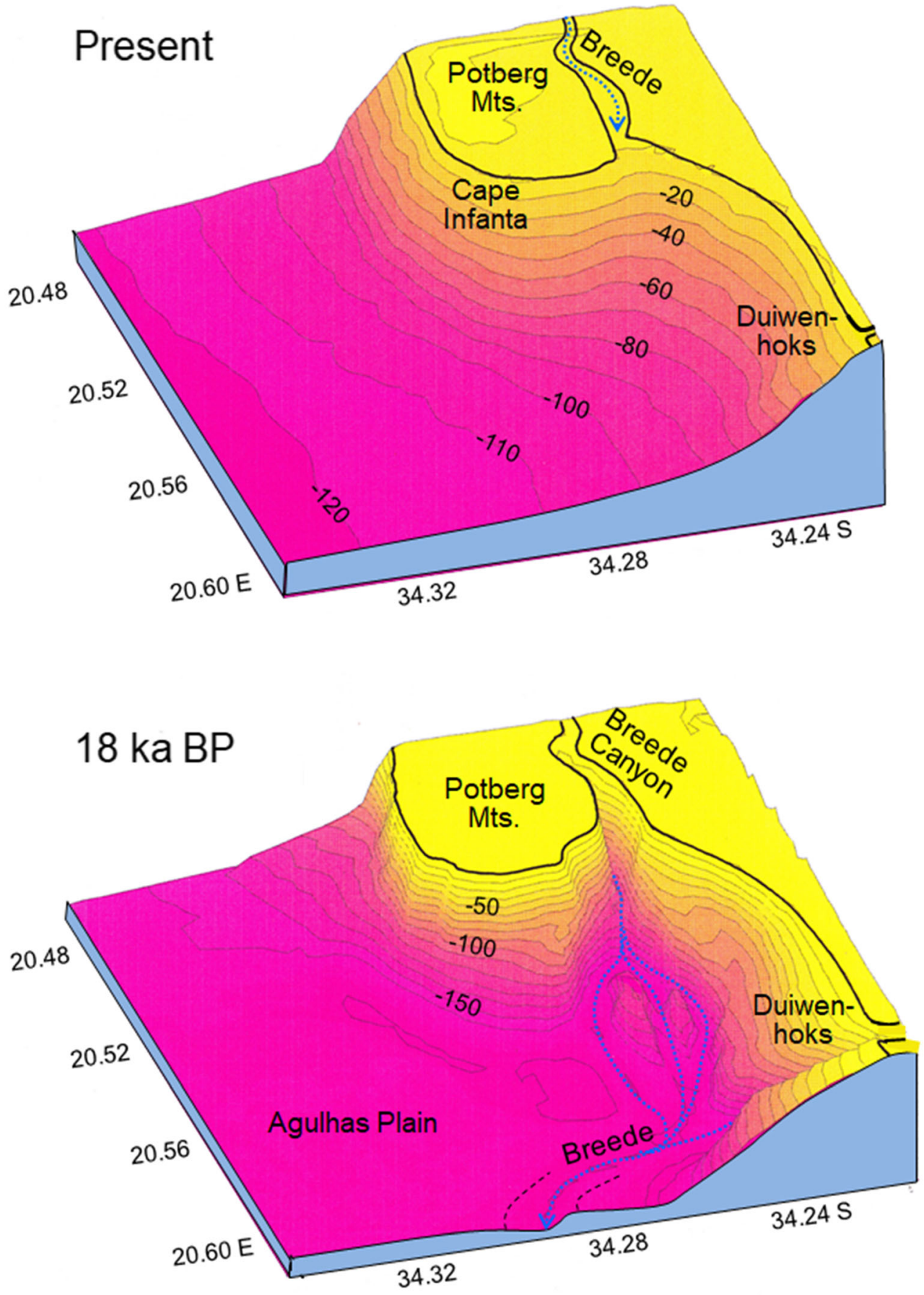

\section{Discussion}

\section{Hydrology}

Several approaches can be followed to establish the estuary type in terms of the mixing state between fresh water and salt water, namely, well-mixed, partially stratified, and wellstratified (Simmons 1955; Hansen and Rattray 1966; Geyer
2010). In the approach of Simmons (1955; cf. also Borrego et al. 1995), fluvial discharges are plotted against the ratios between the tidal discharges (at spring, mean, and neap tides) and high, mean, and low fluvial discharges, respectively. In the approach of Hansen and Rattray (1966; cf. also Prandle 2009), the ratio between the mean vertical salinity difference and the mean vertical salinity (stratification parameter) is plotted against the ratio between the mean vertical velocity and the 
mean surface velocity (circulation parameter). In the approach of Geyer (2010), in turn, river flow velocities are plotted against the tidal flow velocities. As the precise velocity of the fluvial component of the Breede estuary at the time of the survey was unknown, the approach of Simmons (1955) was chosen to illustrate the estuary type and its potential range (Fig. 18). It reveals that the Breede River estuary, on average, ranges from a well-mixed state at low and intermediate discharges to a partially stratified state at mean and high discharges. It also reveals that well-stratified conditions would only be feasible during exceptionally high river discharges, conditions that occur episodically to this day in spite of the large volumes held back in numerous dams. Months with exceptionally high flood events in the period from 1924 to 1987 are illustrated in de Villiers (1988). During such events, the Breede estuary will be well stratified with the potential of complete flushing and resetting of the system (Taljaard 2003). To validate the classification, the salinity gradients observed in the present study (Fig. 10c) were compared with those predicted in more recent model calculations at a variety of Breede River discharges (Taljaard 2003). It was found that the observed salinities are almost identical to those in the model calculation for a river discharge of $\sim 10 \mathrm{~m}^{3} / \mathrm{s}$ ( $\mathrm{cf}$. page C-23 in Taljaard 2003).

The mixed sand/mud reach is the only part of the estuary where the bed sediment contains appreciable amounts of mud (up to $75 \%$; cf. Fig. 14). It is the estuary section over which the turbidity maximum migrates in the course of the falling and

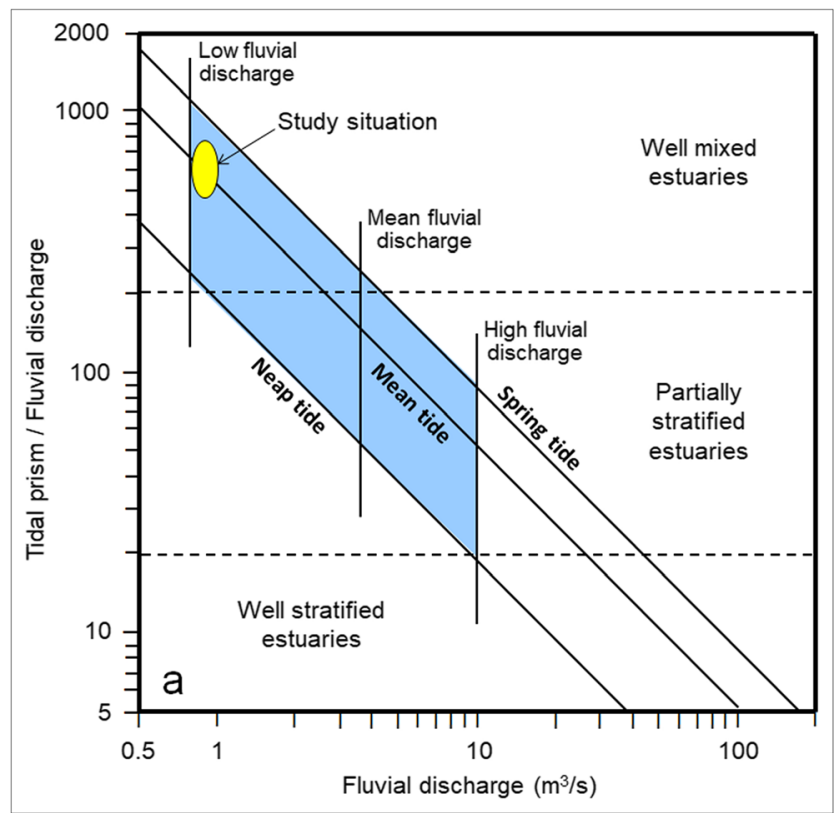

Fig. 18 Diagram illustrating the stratification options for the Breede River estuary at low, mean, and high fluvial discharges as reflected by the relationship of the ratio between the tidal prism and the fluvial discharge (vertical axis) and the fluvial discharge (horizontal axis) based on the approach proposed by Simmons (1955). Note the approximate situation at the time of the survey (yellow ellipse) rising tide. As evident from Fig. 14, the onset of flocculation/ aggregation/agglomeration of the finely dispersed suspended matter in the river water is rather abrupt, initial deposition during slack water periods commencing at $\mathrm{km} 18.5$ and continuing downstream up to about $\mathrm{km} 5$. At the time of the survey, the mud reach thus stretched over a distance of 13.5 $\mathrm{km}$. It should be noted, however, that the length and position of estuarine mud reaches can vary strongly and are dependent on the estuary-specific hydrology (e.g., Friedrichs et al. 1998; Prandle 2009; Schettini et al. 2010).

An interesting feature of the Breede River estuary is that not only the funnel-shaped marine sand reach but also the parts of the mixed sand/mud reach and fluvial sand reach are distinctly flood dominated. Local flood domination in estuaries is not uncommon, especially in lower estuaries characterized by well-developed flood deltas (e.g., Bryce et al. 1998; Schumann et al. 1999; Kang and Jun 2003; Schumann 2003; Wang et al. 2019). Thus, the flood domination of the marine sand reach of the Breede estuary with its large flood delta comes as no surprise. However, the observed flood dominated flow in the upstream parts of the Breede estuary is a phenomenon that has thus far not been documented in other studies (e.g., Taljaard 2003) and, to our knowledge, also not for any other South African estuary (Beck 2005). Detailed physical investigations of this phenomenon have shown that either flood-dominance or ebb-dominance along estuary channels can be explained by the relationship between tidal flow asymmetry (local shear stress differences) and the cross-sectional channel geometry (morphology). Comprehensive treatments of this phenomenon can, for example, be found in Dronkers (1986, 2005), Friedrichs and Aubrey 1988; Friedrichs (1995), Wang et al. (1999), Prandle (2009), and Zhou and Stacey (2020).

\section{Geomorphology and sedimentology}

According to O'Brien (1969), there is a strong correlation between tidal prisms and the corresponding cross-sectional areas of tidal inlets. This relationship has been mathematically expressed as $\mathrm{P}=13,158 \mathrm{~A}_{\mathrm{c}}\left[\mathrm{m}^{3}\right]$, where $\mathrm{P}$ is the tidal volume $\left(\mathrm{m}^{3}\right)$ and $\mathrm{A}_{\mathrm{c}}$ is the cross-sectional area $\left(\mathrm{m}^{2}\right)$ of a tidal inlet below mean sea level. A similar relation with a correlation coefficient of $\mathrm{R}=0.97$ was presented by van den Berg (1986), namely, $\mathrm{V}_{\text {tide }}=12,200 \mathrm{~A}_{\mathrm{c}}+\left(2 \times 10^{6}\right)\left[\mathrm{m}^{3}\right]$, with $\mathrm{V}_{\text {tide }}$ representing the volume of the dominant tide (Fig. 19a). It was based on corresponding data from the Grevelingen inlet and the Oosterschelde inlet and estuary in the Netherlands. Values published by van de Kreeke and Haring (1979) for the Rhine-Meuse delta also fit this relation very well.

The general applicability of the trend described by such relations has in the meantime been confirmed by D'Alpaos et al. (2010) in a detailed modelling study. It was therefore of 
Fig. 19 (a) Diagram illustrating the global relationship between average tidal channel crosssectional areas and associated tidal volumes (extracted from van den Berg 1986). (b) Blow-up showing the location of the Breede River in this diagram. Data point labels 1 and 2 refer to van de Kreeke and Haring (1979), and labels 3 and 4 to van den Berg (1986). Also note the position of the regression (broken line) that was misplotted in van den Berg (1986)

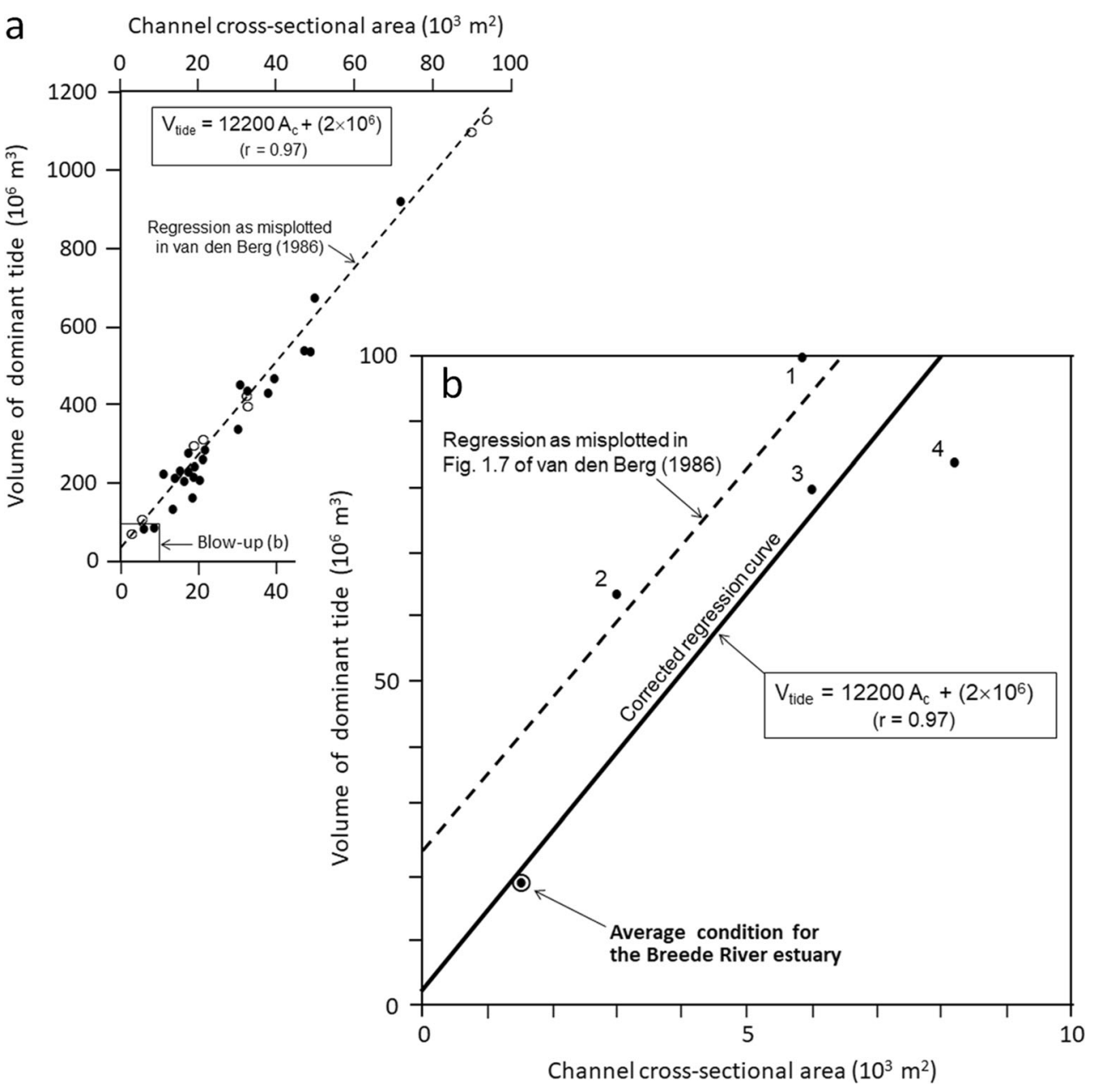

Due to the along-estuary changes in the dominance of ebb and flood tidal flows, bed load transport is not consistently directed downstream from the estuary head towards the mouth but that, as documented by the orientation of the bedforms, opposing directions indicating either ebb or flood domination of the flow (Fig. 12a, b). Such bedform behaviour is not uncommon and has previously been documented for the lower courses of funnel-shaped estuaries (e.g., Harris 1988; Bryce et al. 1998; Kang and Jun 2003; Schumann 2003; Wang et al. 2019), where flood-dominant and ebb-dominant flows are mutually evasive. This is also the case for the funnel-shaped marine sand reach of the Breede estuary, which is dominated by the large flood delta.

An issue concerning the flood delta is the question of whether coarser sand of marine origin has been imported into the estuary over more recent decades. This question was raised by a comparison of aerial photographs from 1942 and 1981 which revealed a progressive loss of a Zostera seagrass meadow located at the shoreward head of the flood delta (Carter 1983). This decline had already been noted by Day (1981), who saw the reason for this in changed sedimentation caused by the decreased river discharge in the wake of dam 
constructions in the upper river catchment. This, in turn, was mooted to have favoured the import of coarse sand of marine origin which eventually smothered the seagrass meadow. This inference was later supported by de Villiers (1988) on the basis of personal observations. However, such textural changes can just as well be explained by gradual current-induced and wave-induced redistribution of the existing sediment on the flood delta which, as pointed out earlier, is a rather dynamic environment. On the other hand, a decline in seagrass habitats has also been observed in other South African estuaries and lagoons (Pillay et al. 2010) and, indeed, worldwide (Orth et al. 2006). This points to other, more globally effective, factors than just local ones.

The opposing sand transport directions in the marine sand reach of the Breede (Fig. 12c) suggest the existence of a sediment recirculation system. In this scheme, sand is transported upstream across the flood delta during flood tides (especially at spring tides) until it reaches the head of the flood delta. Here, it spills into the ebb-dominated main channel from where it is transported downstream towards the mouth. Upon reaching the mouth, it is once more entrained by the flood current to begin a new cycle. The remarkable consistency in the size and shape of the flood delta over the past 154 years actually suggests the existence of a hydraulic equilibrium between the size of the flood delta and the availability of sand.

\section{Holocene evolution}

There is general agreement that the palaeo-Breede River drained towards the west of the Alphard Banks Rise (Dingle and Rogers 1972; Compton 2011; Cawthra et al. 2020a, b). Up to at least 2011, the Duiwenhoks River, the mouth of which is located only $14 \mathrm{~km}$ east of the Breede mouth, was thought to have been a tributary of the Breede during sea-level lowstands (Dingle and Rogers 1972; Compton 2011). More recently, however, the course of the palaeo-Duiwenhoks has been linked to the palaeo-Goukou River, which crosses the palaeo-Agulhas Plain on the eastern side of the Alphards Bank Rise (Cawthra et al. 2020a, b). If this link was correct, then the palaeo-valley of the Duiwenhoks would have to incised into the submarine rock platform to the south and east of the present mouth, while also dissecting the Alphard Banks Rise in order to reach the Goukou palaeo-valley. The data base for such an interpretation, however, is rather thin. Indeed, the seismic data presented in the present study (cf. Fig. 16) strongly argue against such a link. Unfortunately, the new interpretation is currently in the process of being cemented in that corresponding maps are reproduced in publications dealing with entirely different aspects (e.g. Marean et al. 2020). There is thus an urgent need to clarify this unsatisfactory situation.

\section{Conclusions and recommendations}

Taken together, the most important results of this study can be summarized as follows:

- From a physical point of view, the Breede River estuary is a 'well-behaved' estuary when viewed in a global perspective. This suggests that, with the exception of diminished fluvial runoff caused by water retention in numerous dams, physical human impacts are minimal.

- Because current modelling approaches have evidently not been able to identify the flood-dominance of parts of the estuary upstream of $\mathrm{km} 18.5$, it is strongly recommended that such modelling be refined in order to better represent the true nature of the estuary.

- A research programme monitoring the location, size, and dynamics of selected scour pools, combined with the structure of the flow, is recommended in order to obtain a better understanding of the mechanisms responsible for their formation and stability.

- The course of the Duiwenhoks River during sea-level lowstands as proposed by Cawthra et al. (2020a) should be reconsidered in the light of the evidence presented in this study. Alternatively, a more detailed seismic survey should be carried out to clarify the issue once and for all.

Supplementary Information The online version contains supplementary material available at https://doi.org/10.1007/s00367-021-00686-8.

Acknowledgements The authors wish to thank the former National Research Institute for Oceanology (NRIO) of the Council for Scientific and Industrial Research (CSIR) in Stellenbosch (today known under CSIR Coastal Systems, Smart Places) for financing the field work in 1983 and providing laboratory facilities for the analysis of collected samples, measurements and analogue recordings. Alex Fricke $\dagger$, Gerry Rule, and Henri Fortuin are thanked for their assistance in the field and laboratory.

Funding Open Access funding enabled and organized by Projekt DEAL.

\section{Declarations}

Conflict of interest The authors declare that there is no conflict of interest with third parties.

Open Access This article is licensed under a Creative Commons Attribution 4.0 International License, which permits use, sharing, adaptation, distribution and reproduction in any medium or format, as long as you give appropriate credit to the original author(s) and the source, provide a link to the Creative Commons licence, and indicate if changes were made. The images or other third party material in this article are included in the article's Creative Commons licence, unless indicated otherwise in a credit line to the material. If material is not included in the article's Creative Commons licence and your intended use is not permitted by statutory regulation or exceeds the permitted use, you will need to obtain permission directly from the copyright holder. To view a copy of this licence, visit http://creativecommons.org/licenses/by/4.0/. 


\section{References}

Adams JB (2020) Salt marsh at the tip of Africa: patterns, processes and changes in response to climate change. Estuar Coast Shelf Sci 237. https://doi.org/10.1016/j.ecss.2020.106650

Adams JB, Cowie M, van Niekerk L (2016) Assessment of complete ecological water requirement studies for South African estuaries and responses to changes in freshwater inflow. Water Research Commission Report No KV 352/15

Allanson BR, Baird D (eds) (1999) Estuaries of South Africa. Cambridge University Press, Cambridge

Barbier EB, Hacker SD, Kennedy C, Koch EW, Stier AC, Silliman BR (2011) The value of estuarine and coastal ecosystem services. Ecol Monogr 81:169-193

Barletta M, Dantas DV (2016) Fish assemblages. In: Kennish MJ (ed) Encyclopedia of estuaries. Springer, Dordrecht, pp 317-326

Bartholomä A, Ernstsen VB, Flemming BW, Bartholdy J (2004) Bedform dynamics and net sediment transport paths over a floodebb tidal cycle in the Gradyb channel (Denmark), determined by high-resolution multibeam echosounding. Danish J Geogr 104:4555

Beck JS (2005) Sediment transport dynamics in South African estuaries. $\mathrm{PhD}$ thesis, University of Stellenbosch, South Africa

Begg G (1978) The estuaries of natal. Natal Town \& Regional Planning Commission, Pietermaritzburg, Report 41, 657 pp

Birch GF (1980) Nearshore quaternary sedimentation off the south coast of South Africa (Cape Town to Port Elizabeth). Geol Surv S Afr Bull $6720 \mathrm{pp}$

Borrego J, Morales JA, Pendon JG (1995) Holocene estuarine facies along the mesotidal coast of Huelva, south-western Spain. In: Flemming BW, Bartholomä A (eds) Tidal Signatures in Modern and Ancient Sediments, vol 24. IAS Special Publication, Blackwell, pp 151-170

Bryce S, Larcombe P, Ridd PV (1998) The relative importance of landward-directed tidal sediment transport versus freshwater flood events in the Normanby River estuary, Cape York Peninsula, Australia. Mar Geol 149:55-78

Carter RA (1983) Report No. 21: Breë (CSW 22). In: Heydorn AEF, Grindley JR (Eds) Estuaries of the Cape. Part II: Synopsis of available information in individual systems. Estuarine and Coastal Research Unit, NRIO (CSIR), Stellenbosch, CSIR Research Report 420

Carver RE (ed) (1971) Procedures in sedimentary petrology. WileyInterscience, New York $653 \mathrm{pp}$

Cawthra HC, Cowling RM, Ando S, Marean CW (2020a) Geological and soil map of the Palaeo-Agulhas Plain for the last glacial maximum. Quat Sci Rev 235:105858. https://doi.org/10.1016/j.quascirev.2019. 07.040

Cawthra HC, Frenzel P, Hahn A, Compton JS, Gander L, Zabel M (2020b) Seismic stratigraphy of the inner to mid Agulhas Bank. South Africa Quat Sci Rev 235:105979. https://doi.org/10.1016/j. quascirev.2019.105979

Coetzee JC, Adams JB, Bate GC (1996) A botanical importance rating system for estuaries. J Coast Conserv 2:131-138

Compton JS (2011) Pleistocene sea-level fluctuations and human evolution on the southern coastal plain of South Africa. Quat Sci Rev 30: 506-527

Cooper JAG (2001) Geomorphological variability among microtidal estuaries from the wave-dominated South African coast. Geomorphology 40(1):99-122

Cooper JAG, Wright I, Mason T (1999) Geomorphology and sedimentology. In: Allanson BR, Baird D (eds) Estuaries of South Africa. Cambridge University Press, Cambridge, pp 5-25
Cooper JAG, Green AN, Wright CI (2012) Evolution of an incised valley coastal plain estuary under low sediment supply: a 'give-up' estuary. Sedimentology 59:899-916

CSIR (1987) Basic physical geography/hydro data for estuaries of the south-western Cape (CSW 1-26). National Research Institute for Oceanology (CSIR), Stellenbosch, Data Report D8705

Cullis JDS, Rossouw N, du Toit G, Petrie D, Wolfaardt G, de Clercq W, Horn A (2018) Economic risks due to declining water quality in the Breede River catchment. Water SA 44:464-473

D'Alpaos A, Lanzoni S, Marani M, Rinaldo A (2010) On the tidal prismchannel area relations. J Geophys Res 115:F01003

Dalrymple RW, Zaitlin BA, Boyd R (1992) Estuarine fades models: conceptual basis and stratigraphic implications: PERSPECTIVES. J Sediment Res 62:1130-1146

Day JH (1981) Summaries of current knowledge of 43 estuaries in southern Africa. In: Day JH (ed) Estuarine Ecology with Particular Reference to Southern Africa. AA Balkema, Cape Town, pp 251330

De Lecea AM, Green AN, Cooper JAG (2016) Environmental change during the Pleistocene and Holocene: estuaries and lagoons of southern Africa. In: Knight J, Grab SW (eds) Quaternary Environmental Change in Southern Africa: Physical and Human Dimensions. Cambridge University Press, Cambridge, pp 219-233

De Villiers L (1988) Sedimentation changes in the Breede River estuary. MSc thesis, University of Cape Town, South Africa, 198 pp

Dingle RV, Rogers J (1972) Pleistocene palaeogeography of the Agulhas Bank. Trans Roy Soc S Afr 40:155-165

Dionne JC (1963) Towards a more adequate definition of the St. Lawrence estuary. Zeitschr Geomorph 7:36-44

Dronkers J (1986) Tidal asymmetry and estuarine morphology. Neth J Sea Res 20:117-131

Dronkers J (2005) Dynamics of coastal systems. Advanced Series on Ocean Engineering, vol 25. World Scientific, Singapore

Duvenage IR (1983) Surface areas of some tidal rivers along the coast of the Cape (in Afrikaans). Estuarine and Coastal Research Unit, CSIR, Stellenbosch (unpublished report)

DWA (1986) Management of Water Resources of the Republic of South Africa. Department of Water Affairs, Pretoria $300 \mathrm{pp}$

Ernstsen VB, Noormets R, Winter C, Hebbeln D (2005) Development of subaqueous barchanoid-shaped dunes due to lateral grain size variability in a tidal inlet channel of the Danish Wadden Sea. J Geophys Res 110:F04S08

Flemming BW (1988) Process and pattern of sediment mixing in a microtidal coastal lagoon along the west coast of South Africa. In: de Boer PL, van Gelder A, Nio SD (eds) Tide-influenced sedimentary environments and facies. D. Reidel Publ. Co., Dordrecht, pp 275-288

Flemming BW, Thum A (1978) The settling tube - a hydraulic method for grain size analysis of sands. Kieler Meeresforschungen, Sonderheft 4:82-95

Flemming BW, Martin AK (1983) A sedimentological pilot study of the Breede River estuary - observations and implications. Poster F21, 5th National Oceanographic Symposium, January 1983, Rhodes University, Grahamstown, South Africa.

Flemming BW, Hay R (1984) On the bulk density of South African marine sands. Trans Geol Soc S Afr 87:233-236

Flemming BW, Delafontaine M (2016) Mass physical sediment properties. In: Kennish MJ (ed) Encyclopedia of Estuaries. Springer, Dordrecht, pp 419-431

Folk RL, Ward WC (1957) Brazos River bar: a study in the significance of grain size parameters. J Sediment Res 27:3-26

Friedrichs CT (1995) Stability shear stress and equilibrium crosssectional geometry of sheltered tidal channels. J Coast Res 11: 1062-1074 
Friedrichs CT, Aubrey DG (1988) Non-linear tidal distortion in shallow well-mixed estuaries: a synthesis. Estuar Coast Shelf Sci 27:521545

Friedrichs CT, Armbrust BD, de Swart HE (1998) Hydrodynamics and equilibrium sediment dynamics of shallow, funnel-shaped tidal estuaries. In: Dronkers J, Scheffers M (eds) Physics of Estuaries and Coastal Seas. Balkema, Rotterdam, pp 315-327

Geyer RW (2010) Estuarine salinity structure and circulation. In: ValleLevinson A (ed) Contemporary Issues in Estuarine Physics. Cambridge University Press, Cambridge, pp 12-26

Hansen DV, Rattray M (1966) New dimensions on estuarine classification. Limnol Oceanogr 11:319-326

Harris PT (1988) Large-scale bedforms as indicators of mutually evasive sand transport and the sequential infilling of wide-mouthed estuaries. Sediment Geol 57:273-298

Heydorn AEF, Tinley KL (1980) Estuaries of the Cape. Part I. Synopsis of the Cape Coast. Natural features, dynamics and utilization. Stellenbosch, CSIR Research Report 380

Heydorn AEF, Grindley JR (eds) (1982) Estuaries of the Cape. Part II. Synopses of available information on individual systems. Stellenbosch, CSIR Research Report 417

Heydorn AEF, Morant PD (eds) (1989) Estuaries of the Cape. Part II. Synopses of Available Information on Individual Systems. CSIR Research Report No. 436

Illenberger WK (1991) Sediment dynamics of the Sundays estuary, South Africa. Naturalist 35:24-26

Illenberger WK (1992) Sediment dynamics of the Sundays River mouth area, Algoa Bay. PhD thesis, University of Port Elizabeth, Port Elizabeth

Kang JW, Jun KS (2003) Flood and ebb dominance in estuaries in Korea. Estuar Coast Shelf Sci 56:187-196

Kennish MJ (ed) (2016a) Encyclopedia of Estuaries. Springer, Dordrecht, $760 \mathrm{pp}$

Kennish MJ (2016b) Preface. In: Kennish MJ (ed) Encyclopedia of Estuaries. Springer, Dordrecht, $2 \mathrm{pp}$

Lamberth SJ, van Niekerk L, Hutchings K (2008) Comparison of, and the effects of altered freshwater inflow on, fish assemplages of two contrasting South African estuaries; the cool-temperate Olifants and the warm-temperate Breede. Afr J Mar Sci 30:311-336

Le Roux FG (1990) Palaeontological correlation of Cenozoic marine deposits of the southeastern, southern and western coasts, Cape Province. S Afr J Geol 93:514-518

Marean CW, Cowling RM, Franklin J (2020) The Palaeo-Agulhas Plain: temporal and spatial variation in an extraordinary extinct ecosystem of the Pleistocene of the Cape Floristic Region. Quat Sci Rev 235: 106161. https://doi.org/10.1016/j.quascirev.2019.106161

Marker ME (1981) Karst in the Bredasdorp area: a preliminary analysis. S Afr Geogr 9:25-29

Marker ME (1988) Karst. In: Moon BP, Dardis GF (eds) The Geomorphology of Southern Africa. Southern Book Publ, Johannesburg, pp 175-197

McLachlan A, Grindley J (1971) Distribution of macrobenthic fauna of the soft substrata in Swartkops estuary - with observations on the effects of floods. Zool Afr 9:211-233

McLachlan A, Grindley J (1974) Distribution of macrobenthic fauna of the soft substrata in Swartkops estuary - with observations on the effects of floods. Zool Afr 9:211-233

Midgley DC, Pitman WV (1969) Surface water resources of South Africa. Hydrological Research Unit, Department of Civil Engineering, University of Witwatersrand, South Africa, Report 2/69, $128 \mathrm{pp}$

Mueller JR (1968) An Introduction to the hydraulic and topographic sinuosity indexes. Ann Assoc Am Geogr 58:371-385

Nichols MM (1972) Sediments of the James River estuary, Virginia. In: Nelson BW (ed) Environmental framework of Coastal Plain Estuaries, Geol Soc Am Mem, vol 133, pp 571-589
Noble RG, Hemens J (1978) Inland water ecosystems in South Africa-a review of research needs. South African National Science Programme, Pretoria, Report 34, $150 \mathrm{pp}$

O'Brien MP (1969) Equilibrium flow areas of inlets on sandy coasts. ASCE J Waterways Harbors Coastal Eng 95:43-55

Orth RJ, Carruthers TJB, Dennison WJ, Duarte CM et al (2006) A global crisis for seagrass ecosystems. Bioscience 56:987-996

Perillo GME (ed) (1995) Geomorphology and sedimentology of estuaries. Developments in Sedimentology 53, 2nd edn. Amsterdam, Elsevier Science

Perkins EJ (1974) The biology of estuaries and coastal waters. Academic Press, New York

Pillay D, Branch GM, Griffiths CL, Williams C, Prinsloo A (2010) Ecosystem change in a South African marine reserve (1960 2009): role of seagrass loss and anthropogenic disturbance. Mar Ecol Prog Ser 415:35-48

Pitman WV, Potgieter DJ, Middleton BJ, Midgley DC (1982) Surface water resources of South Africa. Volume IV. Drainage regions EGHJKL, Western Cape. Part 1. Dept. of Civil Engineering, University of Witwatersrand, HRU Report No 13/81

Prandle D (2009) Estuaries: dynamics, mixing, sedimentation and morphology. Cambridge University Press, Cambridge, 236 pp

Reddering JSV (1983) An inlet sequence produced by migration of a small microtidal inlet against longshore drift: the Keurbooms inlet, South Africa. Sedimentology 40:201-218

Reddering JSV (1988) Coastal and catchment basin controls on estuary morphology of the south-eastern Cape coast. S Afr J Sci 84:154-157

Reddering JSV, Esterhuysen K (1984) Sedimentation in the Knysna estuary. University of Port Elizabeth, ROSIE Report 8, 79 pp

Reddering JSV, Rust IC (1990) Historical changes and sedimentary characteristics of southern African estuaries. S Afr J Sci 86:425-428

Rooseboom A (1978) Sediment delivery of South African rivers (in Afrikaans). Water South Africa 4:14-17

Schettini CAF, de Almeida DC, Siegle E, de Alencar ACB (2010) A snapshot of suspended sediment and fluid mud occurrence in a mixed-energy embayment, Tijucas Bay, Brazil. Geo-Mar Lett 30: 47-62. https://doi.org/10.1007/s00367-009-0152-8

Schumann EH (ed) (2003) Towards the management of marine sedimentation in South African estuaries with special reference to the eastern Cape. WRC Report No. 1109/1/03

Schumann EH (2013) Sea level variability in South African estuaries. S Afr J Sci 109:22-28

Schumann E (2015) Keurbooms estuary floods and sedimentation. S Afr J Sci 111:95-103

Schumann EH, Largier JL, Slinger JH (1999) Estuarine hydrodynamics. In: Allanson BR, Baird D (eds) Estuaries of South Africa. Cambridge University Press, Cambridge, pp 27-52

Scott A, Scott M (2001) The Overberg explorer-a guide for environment-oriented travel in the Overberg. Overberg Conservation Services, Gansbaai 199 pp

Simmons HB (1955) Some effects of upland discharge on estuarine hydraulics. Proc ASCE 81:1-20

Taljaard S (2003) Intermediate determination of resource directed measures for the Breede River estuary. CSIR, Stellenbosch, Report ENV-S-C 2002-020/A

Taljaard S, van Niekerk L, Huizinga P (2001) Breede River estuary EFR/ RDM study. Draft Specialist Report on Physical Dynamics and Water Quality. CSIR Report ENV-S-C 2001

Taljaard S, van Niekerk L, Joubert W (2009) Extension of a qualitative model on nutrient cycling and transformation to include microtidal estuaries on wave-dominated coasts: southern hemisphere perspective. Estuar Coast Shelf Sci 85:407-421

Thamm AG, Johnson MR (2006) The Cape Supergroup. In: Johnson MR, Anhaeusser CR, Thomas RJ (eds) The Geology of South Africa. Council for Geoscience, Pretoria, pp 443-460 
Turpie JK, Adams JB, Joubert A, Harrison TD, Colloty BM, Maree RC, Whitfield AK, Wooldridge TH, Lamberth SJ, Taljaard S, van Niekerk L (2002) Assessment of the conservation priority status of South African estuaries for use in management and water allocation. Water SA 28:191-206

Van de Kreeke J, Haring J (1979) Equilibrium flow areas in the RhineMeuse delta. Coast Eng 3:97-111

Van den Berg JH (1986) Introduction. In: van den Berg JH (ed) Aspects of sediment- and morphodynamics of subtidal deposits of the Oosterschelde (The Netherlands), vol 43. Rijkswaterstaat, The Hague, Communications, pp 12-34

Van Niekerk L, Adams JB, Lamberth SJ, MacKay F, Taljaard S, Turpie JK, Weerts S, Raimondo DC (2019) South African National Biodiversity Assessment 2018 Tech Rept 3: Estuarine Realm. CSIR Report Number CSIR/SPLA/EM/EXP/2019/0062/A

Van Niekerk L, Adams JB, James NC, Lamberth SJ, MacKay CF, Turpie JK, Rajkaran A, Weerts SP, Whitfield AK (2020) An estuary ecosystem classification that encompasses biogeopgraphy and a high diversity of types in support of protection and management. Afr J Aquat Sci 45:199-216

Wang ZB, Jeuken C, de Vried HJ (1999) Tidal asymmetry and residual sediment transport in estuaries. Delft Hydraulics, Delft, Report Z2749
Wang ZB, Vandenbruwaene W, Taal M, Winterwerp H (2019) Amplification and deformation of tidal wave in the Upper Scheldt Estuary. Ocean Dyn 69:829-839

Wentworth CK (1922) A scale of grade and class terms clastic sediments. J Geol 30:377-392

Whitfield AK, Bate GC, Adams JB, Cowley PD, Froneman PW, Gama PT, Strydom NA, Taljaard S, Theron AK, Turpie JK, van Niekerk L, Wooldridge TH (2012) A review of the ecology and management of temporarily open/closed estuaries in South Africa, with particular emphasis on river flow and mouth state as primary drivers of these systems. Afr J Mar Sci 34:163-180

Whitfield AK, Baliwe NG (2014) A century of science in South African estuaries: bibliography and review of research trends. SANCOR Occasional Report 7, 289 pp

Wybergh W (1919) The coastal limestones of the Cape Province. Trans Geol Soc S Afr 22:46-67

Zhou J, Stacey MT (2020) Residual sediment transport in tidally energetic estuarine channels with lateral bathymetric variation. J Geophys Res Oceans (online) 125. https://doi.org/10.1029/2020JC016140

Publisher's note Springer Nature remains neutral with regard to jurisdictional claims in published maps and institutional affiliations. 